\title{
Seven year satellite observations of the mean structures and variabilities in the regional aerosol distribution over the oceanic areas around the Indian subcontinent
}

\author{
S. K. Nair, K. Parameswaran, and K. Rajeev \\ Space Physics Laboratory, Vikram Sarabhai Space Centre, Trivandrum 695 022, India \\ Received: 16 February 2005 - Revised: 30 May 2005 - Accepted: 2 June 2005 - Published: 15 September 2005
}

\begin{abstract}
Aerosol distribution over the oceanic regions around the Indian subcontinent and its seasonal and interannual variabilities are studied using the aerosol optical depth (AOD) derived from NOAA-14 and NOAA-16 AVHRR data for the period of November 1995-December 2003. The air-mass types over this region during the Asian summer monsoon season (June-September) are significantly different from those during the Asian dry season (November-April). Hence, the aerosol loading and its properties over these oceanic regions are also distinctly different in these two periods. During the Asian dry season, the Arabian Sea and Bay of Bengal are dominated by the transport of aerosols from Northern Hemispheric landmasses, mainly the Indian subcontinent, Southeast Asia and Arabia. This aerosol transport is rather weak in the early part of the dry season (NovemberJanuary) compared to that in the later period (FebruaryApril). Large-scale transport of mineral dust from Arabia and the production of sea-salt aerosols, due to high surface wind speeds, contribute to the high aerosol loading over the Arabian Sea region during the summer monsoon season. As a result, the monthly mean AOD over the Arabian Sea shows a clear annual cycle with the highest values occurring in July. The AOD over the Bay of Bengal and the Southern Hemisphere Indian Ocean also displays an annual cycle with maxima during March and October, respectively. The amplitude of the annual variation is the largest in coastal Arabia and the least in the Southern Hemisphere Indian Ocean. The interannual variability in AOD is the largest over the Southeast Arabian Sea (seasonal mean AOD varies from 0.19 to 0.42) and the northern Bay of Bengal (seasonal mean AOD varies from 0.24 to 0.39 ) during the February-April period and is the least over the Southern Hemisphere Indian Ocean. This study also investigates the altitude regions and pathways of dominant aerosol transport by combining the AOD distribution with the atmospheric circulation.
\end{abstract}

Keywords. Atmospheric composition and structure (Aerosols and particles) - Meteorology and atmospheric dynamics (Climatology) - Oceanography: physical (Ocean fog and aerosols)

Correspondence to: K. Parameswaran

(k_parameswaran@vssc.org)

\section{Introduction}

The effects of aerosols on the radiation budget of the Earthatmosphere system, cloud characteristics and the Earth's climate are well recognised (Charlson et al., 1992; Hansen et al., 1997; Ramanathan et al., 2001a,b). Annual variation of tropospheric circulation and the resulting aerosol transport over the oceanic regions around the Indian subcontinent are unique because the Inter Tropical Convergence Zone (ITCZ) has the largest annual migration over this part of the globe. Over the Indian longitude the ITCZ, which is located around $15-20^{\circ} \mathrm{S}$ in the February-March period, moves to $20-25^{\circ} \mathrm{N}$ during the Asian summer monsoon period of June-September. As a result, the Arabian Sea, Bay of Bengal and the tropical Indian Ocean encounter contrasting airmass types in these two periods. The prevailing lower tropospheric wind in this region during the Asian dry season has a dominant northerly component directed from the continents to the ocean. This flow pattern enables transport of continental aerosols over to the Arabian Sea, Bay of Bengal and Indian Ocean, as revealed by several studies (e.g. Husar et al., 1997; Krishnamurti et al., 1998; Rajeev et al., 2000; Leon et al., 2001; Li and Ramanathan, 2002; Satheesh and Srinivasan, 2002; Tahnk and Coakley, 2002; Nair et al., 2003; Ramachandran, 2004). This aerosol transport is aided by the relatively large aerosol residence time (about 10 days) caused by the prevailing large-scale dryness during the Asian dry period (Lelieveld et al., 2001). The lower tropospheric circulation and the strength of the lower tropospheric inversion during this season also show significant year-to-year variabilities. This leads to a large interannual variability in aerosol distribution over the Arabian Sea and Bay of Bengal (Nair et al., 2003). During the June-September period, due to the intense low pressure zone generated in the northwestern parts of the Indian subcontinent, the ITCZ migrates north and brings the massive Asian summer (southwest) monsoon over to this region. During this season horizontal pressure gradient and lower tropospheric wind speeds over the Indian subcontinent and adjoining oceanic regions are significantly larger than those during the Asian dry period. Though this season is characterised by high rainfall in the region east of the central Arabian Sea, leading to increased aerosol removal 
through washout and rainout (thereby reducing aerosol residence time), large-scale transport of aerosols through the prevailing strong lower and mid tropospheric westerlies (Rajeev et al., 2004) is quite significant.

Regional distribution and transport of aerosols over the oceanic regions around the Indian subcontinent observed using satellite data showed large interannual variability (Rajeev and Ramanathan, 2000; Li and Ramanathan, 2002; Tahnk and Coakley, 2002; Nair et al., 2003; Rajeev et al., 2004). But most of these observations were based on a limited data length of 3 to 4 years, a good number of which were based on the observation period of 1998-1999 around the Indian Ocean Experiment (INDOEX) (Ramanathan et al., 2001a). These observations, however, showed that AOD values during the March and April period of 1999 over the southeast Arabian Sea and northern Bay of Bengal were larger than those during the corresponding periods of 1997 and 1998 by a factor of 1.5 to 2 (Nair et al., 2003). This brought out the need for establishing a regional mean aerosol distribution that is truly representative for this region and to quantify the year-to-year variability in AOD using a larger database.

The continuous series of data from the Advanced Very High Resolution Radiometer (AVHRR) on board the NOAA14 and NOAA-16 satellites provide an opportunity to study the regional distribution of aerosols and their interannual variability over the oceanic areas around the Indian subcontinent bounded by $25^{\circ} \mathrm{N}$ to $25^{\circ} \mathrm{S}$ in latitude and $40^{\circ} \mathrm{E}$ to $100^{\circ} \mathrm{E}$ in longitude, using a longer period data. Here we report the mean structures in the monthly and seasonal mean regional aerosol distribution and their interannual variabilities based on the AOD derived from NOAA-14 and NOAA16 AVHRR data during the seven-year period from November 1995 to December 2003.

\section{Data and method of analysis}

The AOD at the wavelength $630 \mathrm{~nm} \pm 50 \mathrm{~nm}$ over the oceanic regions around the Indian subcontinent is derived from the radiance measured in Channel 1 of NOAA-14/NOAA-16 AVHRR during the period of November 1995 to December 2003. Due to the delay in the equatorial crossing time of NOAA-14, the solar zenith angle for most of the pixels was very high in the anti-solar side of the scan during 2000. This leads to a larger uncertainty in the derived AOD values. Hence we have used NOAA-14 data only up to December 1999. The NOAA-16 data is available only from March 2001. This has resulted in a data gap of 14 months, from January 2000 to February 2001 in the present study. The method of deriving AOD from the satellite data, the sources of errors, and the intercomparison of the AOD derived from AVHRR data with in-situ measurements are presented elsewhere (Rajeev et al., 2000; Rajeev and Ramanathan, 2000; Parameswaran et al., 2004; Rajeev et al., 2004). The global area coverage (GAC) data of the afternoon satellite passes are used for the retrieval of AOD. Revised post-launch calibration constants, which correct for the degradation of the
AVHRR channel 1 sensor, are used to convert the digital counts to reflectance (Rao and Chen, 1999, and calibration updates from NOAA website at http://noaasis.noaa.gov). Retrieval of AOD is based on the comparison of the observed satellite radiance at channel 1 with the look-up tables of modelled radiances. The look-up tables of satellite radiances as a function of solar zenith angle, the satellite viewing angle, relative azimuth, surface wind speed, and AOD are generated using the discrete ordinate radiative transfer method (Stamnes et al., 1998) for a plane parallel atmosphere with 32 layers in vertical which accounts for the multiple scattering and absorption by aerosols and molecules (Rajeev et al., 2000). In order to minimize errors in the retrieval of AOD, we use the data only from the anti-solar side of the satellite scan. Variations in ocean reflectance due to wind speed are taken into account by considering daily surface winds from the NCEP/NCAR reanalysis. Clear sky pixels that are not adjacent to cloudy pixels are only used for the estimation of AOD. Identification of the clear sky pixels is done based on the threshold, channel ratio and spatial coherence methods (Rajeev and Ramanathan, 2000).

The aerosol scattering phase function and single scattering albedo are required for deriving AOD from the satellitemeasured radiance. The scattering and absorption properties of aerosols used in deriving the AOD for the summer monsoon period and the Asian dry period are explained in Rajeev et al. (2004). Extensive observations of the scattering and absorbing properties of aerosols carried out over the Indian Ocean during the Asian dry season of 1998 and 1999, particularly in the January-March period as part of INDOEX, are used to derive the aerosol scattering phase function for the estimation of AOD during the Asian dry season. The single scattering albedo at the surface is taken as 0.90 with a column integrated value of 0.87 , which is in agreement with the in-situ observations (Ramanathan et al., 2001a). These values are also in agreement with those reported by Eck et al. (2001), using the aerosol data obtained at the Kaashidhoo Climate Observatory (KCO), Maldives, during the JanuaryApril period of 1998-2000. It is interesting to note that the Angstrom exponent observed at KCO is very consistent (between 0.97 and 1.24) during the November to April period (Holben et al., 2001). Unlike the Asian dry season, exhaustive measurements of aerosol properties are lacking over the oceanic areas around the Indian subcontinent during the summer monsoon period. However, several satellite-based observations have demonstrated that the aerosol distribution over the Arabian Sea and Indian Ocean are significantly influenced by the transport of dust aerosols from the Arabian Desert (Husar et al., 1997; Li and Ramanathan, 2002; Rajeev et al., 2004). Two channel inversion of Mishchenko et al. (1999) showed that the Angstrom exponent is very nearly uniform over the Arabian Sea, Bay of Bengal and the tropical Indian Ocean and has a mean value of $\sim 0.4$ during the summer monsoon period, which is grossly in agreement with the Angstrom exponent observed at Bahrain (Holben et al., 2001; Dubovik et al., 2002), the Indian Ocean island of Kaashidhoo (Holben et al., 2001) and the ship-borne observations at 
the Arabian Sea (Vinoj and Satheesh, 2003). Kaufman et al. (2001) showed that the dust aerosols are less absorbing and have a mean single scattering albedo of 0.97 in the visible region. Dubovik et al. (2002) reported aerosol single scattering albedo between 0.92 and 0.95 in the visible region over Bahrain during the Asian summer monsoon period. The dust-laden air from the Saharan region is also found to have an aerosol single scattering albedo around 0.93 . The model presented by Takemura et al. (2002) suggests aerosol single scattering albedo of $\sim 0.9$ to 0.95 over this region during the summer monsoon period. Considering the above observations and models, in the present study, we assume that during the summer monsoon period the aerosol size distribution is of modified power law (MPL) type, yielding an Angstrom exponent of 0.4, in accordance with the reports of Mishchenko et al. (1999) and the single scattering albedo of these aerosols is 0.93 .

The satellite derived AODs are compared with the groundbased measurements of AOD, as described in Rajeev and Ramanathan (2000); Parameswaran et al. (2004); Rajeev et al. (2004) and hence are not repeated here. The satellite retrieved AOD during the Asian dry season is compared with the ground-based measurements of AOD at Kaashidhoo, as well as ship-borne observations (Rajeev and Ramanathan, 2000) over the Arabian Sea and Indian Ocean. The slope of the intercomparison between the two during the Asian dry period is 0.98 with an intercept of 0.02 . The correlation coefficient is 0.92. The RMS deviation between the AVHRRderived and the ground-measured of AOD is 0.055. A comparison of the monthly mean AOD obtained from groundbased measurements at $\mathrm{KCO}$ ( $\mathrm{Li}$ and Ramanathan, 2002) with that of the present AVHRR-derived AOD indicates that the values are in agreement within 0.03 , except for one case in which the difference is 0.07 (Rajeev et al., 2004). Sensitivity analysis of the satellite derived AOD due to variations in the assumed aerosol phase function, the single scattering albedo, the surface reflectance and the AVHRR calibration constants, was also carried out (Rajeev et al., 2000; Rajeev and Ramanathan, 2000; Rajeev et al., 2004). Based on these, the maximum uncertainty of the AVHRR derived AOD is approximately $15 \%$ during the Asian dry season. Considering the non-availability of in-situ measured chemical and radiative properties of aerosols, the maximum uncertainty in AVHRR-derived AOD during the summer monsoon season is expected to be slightly larger but less than $20 \%$.

\section{Results}

\subsection{Spatial distribution of aerosol optical depth}

Aerosol optical depths are derived only from the pixels that are not affected by clouds. Furthermore, the solar side of the satellite scan is avoided in deriving AOD. The pixelwise AOD values for each satellite pass in the latitude-longitude range of $25^{\circ} \mathrm{S}$ to $25^{\circ} \mathrm{N}$ and $40^{\circ} \mathrm{E}$ to $100^{\circ} \mathrm{E}$ are gridded at $1^{\circ}$ by averaging the AOD values derived from all the clear sky individual pixels within the grid box. The frequency of occurrence of clouds in the Arabian Sea and Bay of Bengal regions are distinctly different during each season. North of the equator the fractional cloudiness is generally less than $30 \%$ during the November to April period and is lowest (less than $20 \%$ ) between $10^{\circ} \mathrm{N}$ and $25^{\circ} \mathrm{N}$ for all the longitudes in this region during the January to March period. During the Asian dry season, south of the equator up to about $20^{\circ} \mathrm{S}$, due to the presence of ITCZ, the fractional cloudiness is generally more than $60 \%$. During the summer monsoon period, north of equator over the central and east Arabian Sea, Indian peninsula and Bay of Bengal, the fractional cloudiness is generally greater than $60 \%$ and often exceeds $70 \%$ in July and August. During the Asian dry season, the number of days in which AOD values could be derived for each $1^{\circ} \times 1^{\circ}$ grid is more than 10 per month except between 0 to $20^{\circ} \mathrm{S}$, where the number of days in which AOD could be derived for each grid is around 5 per month (Rajeev and Ramanathan, 2000). At the western Arabian Sea close to the coast where the fractional cloudiness is less than $30 \%$ throughout the summer monsoon, the AOD values are available for more than 10 days per month. Similar is the case for the region over the Indian Ocean south of around $15^{\circ} \mathrm{S}$ during this season (Rajeev et al., 2004).

A seven-year (1996-1999, 2001-2003) average of the monthly mean regional aerosol distribution over oceanic areas around the Indian subcontinent is obtained by averaging the satellite derived AOD in the same month for different years during the study period and this is shown in Fig. 1. The arrows indicate that the monthly mean vector wind field at 850-hpa (approximately $1.5 \mathrm{~km}$ above MSL) level prevailed in this region. The aerosol distribution clearly undergoes a notable annual variation over most of the regions in the Northern Hemisphere as discussed below:

1. The mean AOD over the west Arabian Sea, close to the Arabian coast is less than 0.2 during January-February, and increases to 0.3 in the March-May period. By June, AOD in this region increases drastically (exceeding 0.4) and reaches its highest value, exceeding 0.5 in July followed by a decrease to $\sim 0.3$ by September. The AOD and its spatial distribution remain more or less stable during the period November to January.

2. The mean AOD over the east Arabian Sea, close to the Indian peninsula is less than 0.3 during JanuaryFebruary. This value increases to $\sim 0.4$ in the MarchApril period, especially at the southeast Arabian Sea, while it remains less than 0.3 over the northeast part. Though the AOD values over the east Arabian sea show a small decrease up to June, by July-August the entire Arabian sea region is characterized by high values of AOD. By November-December, the AOD values resume to the level that is observed in January. From November the spatial pattern of AOD also restores slowly to its January pattern through December. 

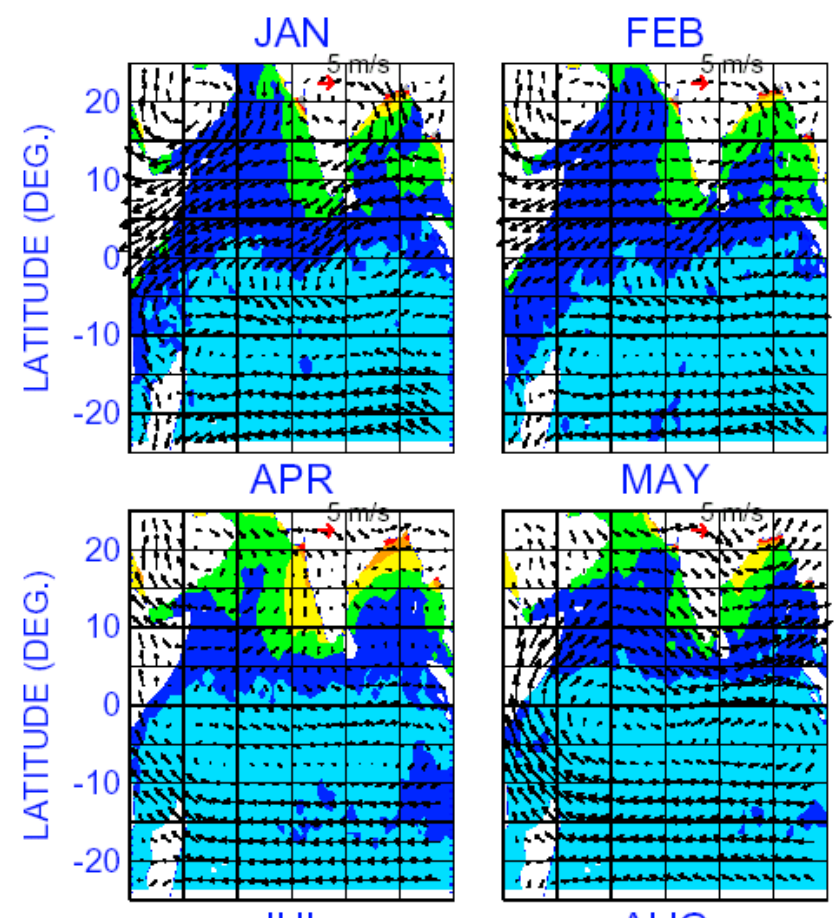

JUL
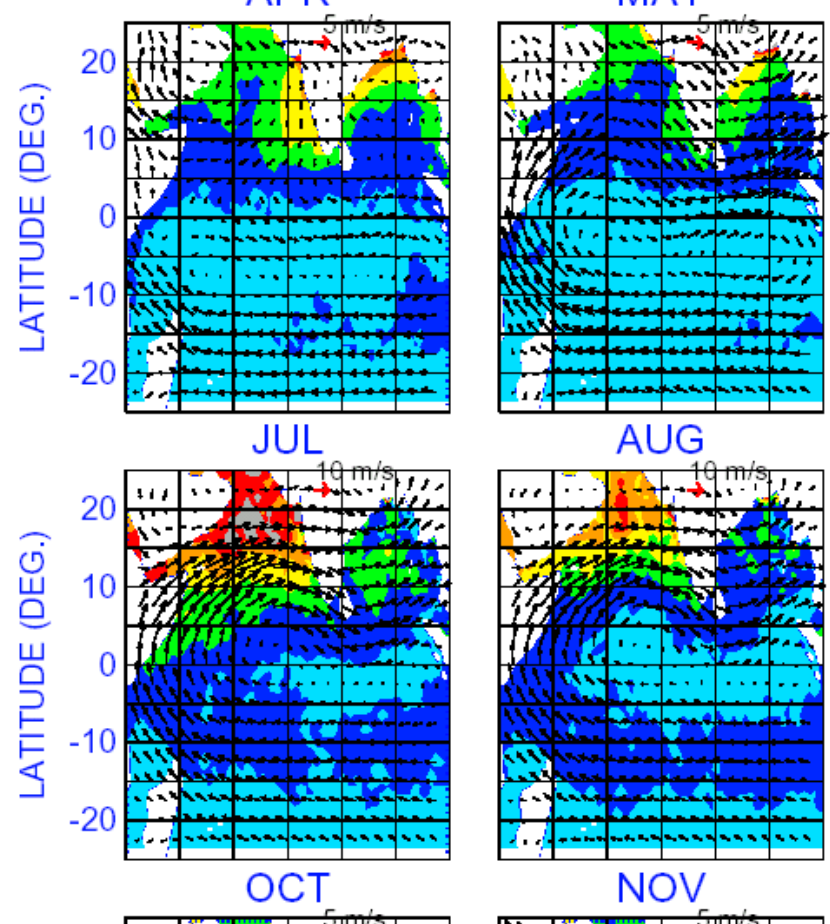

AUG

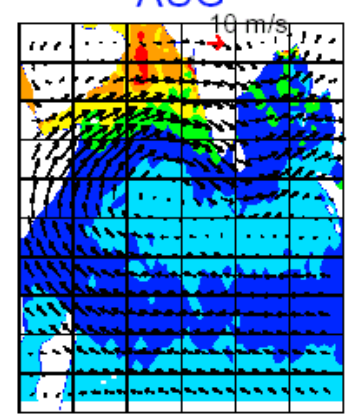

NOV
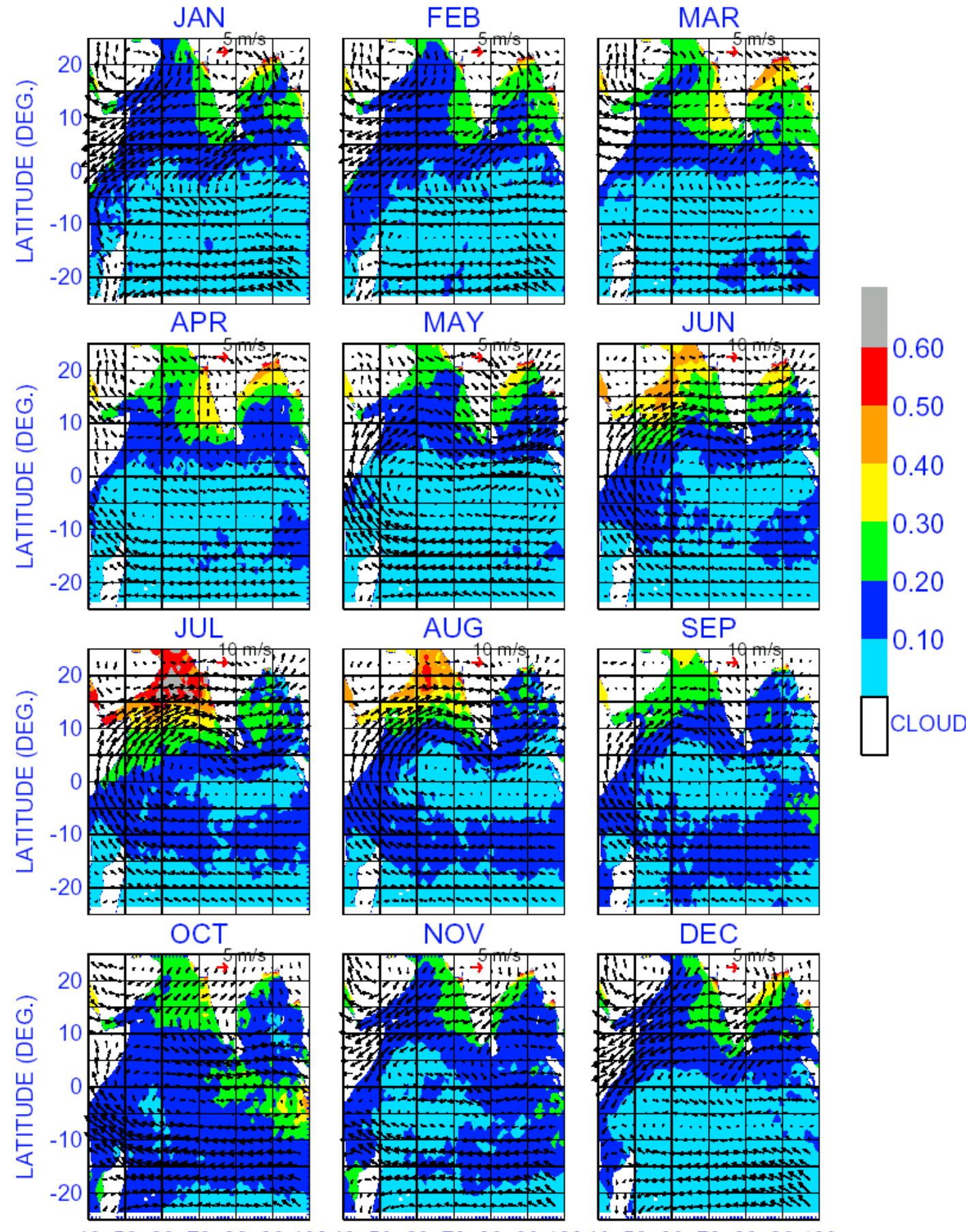

405060708090100405060708090100405060708090100 LONGITUDE (DEG.) LONGITUDE (DEG.) LONGITUDE (DEG.)

Fig. 1. Spatial distribution of monthly mean AOD (at 630 $\pm 50 \mathrm{~nm}$ ) averaged for seven years (1996-1999, 2001-2003) over oceanic areas around the Indian subcontinent, along with the monthly mean wind vectors at 850-hpa level.

3. Over the northwest Bay of Bengal, relatively large AOD values exceeding 0.3 are observed over a small region close to the Indian Peninsula during January-June. In January-February over the rest of the region, AOD decreases with increasing distance from the continent.
This high in AOD and its spatial extent increase, reaching their respective maxima in April ( $\sim 0.4)$ followed by a decrease then onwards and a reduction to $\mathrm{AOD}<0.2$ by September, and again an increase from October. The $\mathrm{AOD}$ and its spatial distribution in this region during 
December are very similar to those observed in January. This shows that the temporal variation of AOD and its spatial distribution are distinctly different in the western and eastern parts of Indian Peninsula.

4. The western parts of Bay of Bengal have AOD values between 0.2 to 0.3 during the January-April period and $<0.2$ during the May to November period. By December, the AOD value exceeds 0.2 over some parts in this region.

5. A minimum in AOD is observed in the central Bay of Bengal throughout the year.

6. From January to May in most of the places over the Southern Hemisphere Indian Ocean (SHIO), the AOD values are generally $<0.1$ except over a small region close to $\sim 15^{\circ} \mathrm{S}$ where it exceeds 0.15 . It increases marginally in the June-November period and is in the range of 0.1 to 0.2 in the latitude belt $\sim 5^{\circ} \mathrm{S}$ to $15^{\circ} \mathrm{S}$. In general, AOD is highest in October (between 0.2 and 0.3 ) in the western parts near Sumatra and Indonesia, followed by a decrease, to reach its background value by December-January.

\subsection{Annual variation in different sectors}

The annual variation in the regional mean AOD over three distinct regions viz. the Arabian Sea $\left(5^{\circ} \mathrm{N}\right.$ to $24^{\circ} \mathrm{N}, 45^{\circ} \mathrm{E}$ to $\left.77^{\circ} \mathrm{E}\right)$, the Bay of Bengal $\left(5^{\circ} \mathrm{N}\right.$ to $22^{\circ} \mathrm{N}, 80^{\circ} \mathrm{E}$ to $\left.100^{\circ} \mathrm{E}\right)$, and the Southern Hemisphere Indian Ocean (0 to $25^{\circ} \mathrm{S}, 40^{\circ} \mathrm{E}$ to $100^{\circ} \mathrm{E}$ ) are examined in detail. The monthly values of AOD in these regions for the study period are presented in Fig. 2, along with vertical bars indicating the standard deviations. Over the Arabian Sea, the regional mean AOD is maximum in July $(\sim 0.34)$ and minimum $(\sim 0.17)$ in November. A secondary maximum is also observed in the March to April period ( $\sim 0.22)$, which is contributed by high AOD values in the southeast Arabian Sea near the Indian peninsula. The large standard deviations during the March to July period when the mean AOD is relatively high are due to larger spatial gradients and the interannual variability in AOD associated with variations in lower tropospheric circulation, which will be discussed later. Over the Bay of Bengal, the mean AOD is high during the November-April period with a peak (0.26) during March and a low $(\sim 0.12)$ in the AugustSeptember period. The standard deviations are also large in February-April and June-July. The annual variation in the mean AOD is less significant over the Southern Hemisphere Indian Ocean $(\mathrm{SHIO})$, where the highest values $(\sim 0.12)$ are encountered in October and lowest values $(\sim 0.07)$ during the December-May period. The standard deviation is also large in October, showing large spatial and temporal variability.

\subsection{Latitude variation of AOD}

The latitude variation in the monthly mean AOD in five different longitude sectors viz. the West Arabian Sea (WAS; $40^{\circ} \mathrm{E}$ to $\left.60^{\circ} \mathrm{E}\right)$, Central Arabian Sea (CAS; $60^{\circ} \mathrm{E}$ to $\left.70^{\circ} \mathrm{E}\right)$,

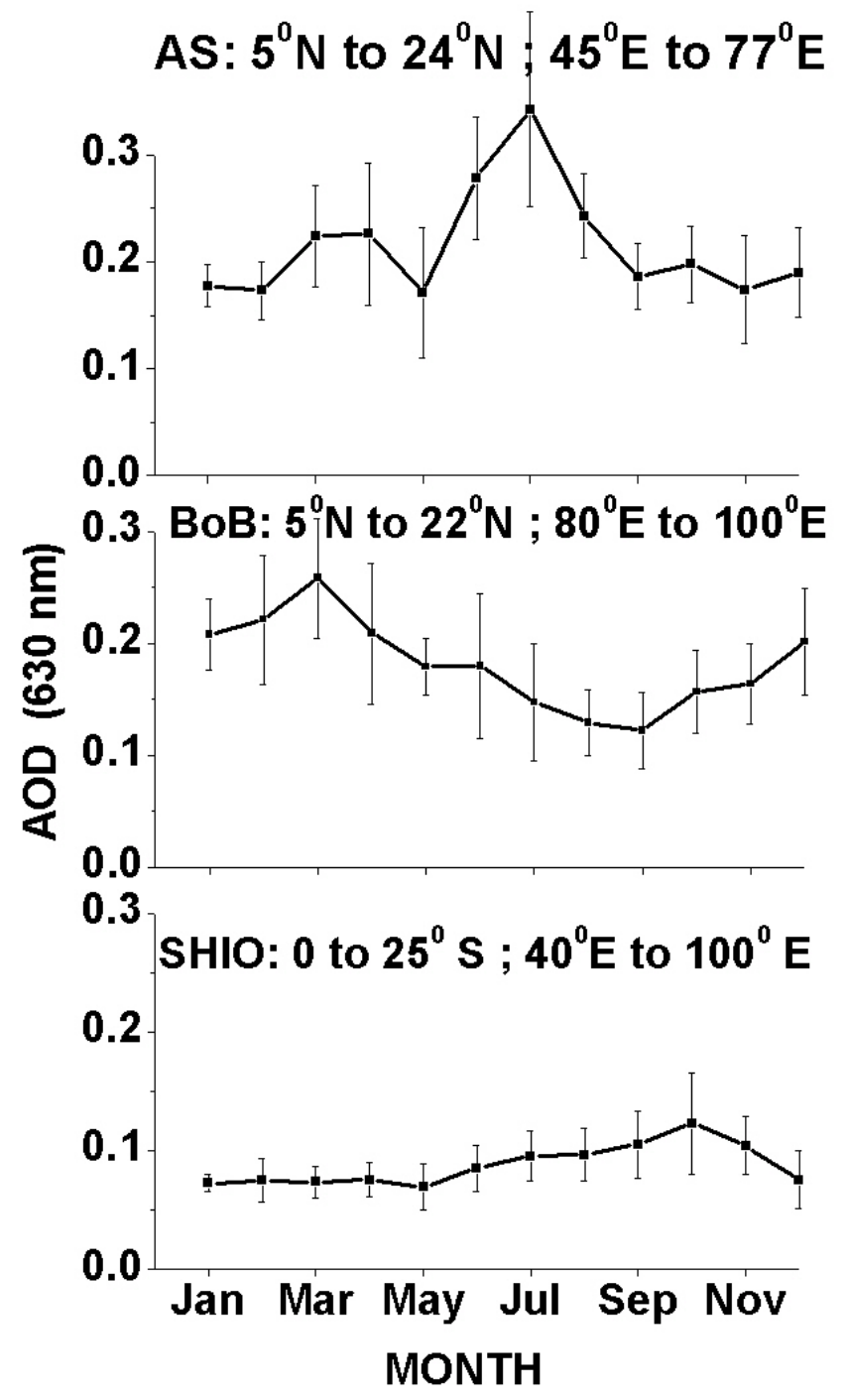

Fig. 2. Monthly variation of AOD averaged for 7 years from 19961999, 2001-2003 for the Arabian Sea $\left(5^{\circ} \mathrm{N}\right.$ to $24^{\circ} \mathrm{N} ; 45^{\circ} \mathrm{E}$ to $\left.77^{\circ} \mathrm{E}\right)$, Bay of Bengal $\left(5^{\circ} \mathrm{N}\right.$ to $22^{\circ} \mathrm{N} ; 80^{\circ} \mathrm{E}$ to $\left.100^{\circ} \mathrm{E}\right)$ and Southern Hemispheric Indian Ocean (0 to $25^{\circ} \mathrm{S} ; 40^{\circ} \mathrm{E}$ to $\left.100^{\circ} \mathrm{E}\right)$.

East Arabian Sea (EAS; $70^{\circ} \mathrm{E}$ to $\left.80^{\circ} \mathrm{E}\right)$, West Bay of Bengal (WBoB; $80^{\circ} \mathrm{E}$ to $\left.90^{\circ} \mathrm{E}\right)$ and East Bay of Bengal (EBoB; $90^{\circ} \mathrm{E}$ to $100^{\circ} \mathrm{E}$ ) are examined in detail. These sectors are selected such that the spatial variations along the longitude are insignificant. It may also be noted that even though these sectors are taken with a fixed longitudinal width of $10^{\circ}$, since no AOD data will be available over the land, the number of AOD values averaged for each latitude will not be the same in all longitude sectors. In those sectors for a given latitude that encounters more continental regions the available number of AOD values will be small and as such, these should be treated cautiously. Additionally, cloud cover also limits the number of AOD values in different sectors, especially near the northern continents during the monsoon period as described in Sect. 3.1. The monthly mean values of AOD for 
each latitude in these longitude sectors are estimated by averaging the corresponding $1^{\circ} \times 1^{\circ}$ grided AOD data for a latitudinal width of $\pm 0.5^{\circ}$ centred around latitude. These mean values of AOD in each month are examined to study the latitudinal variation in different longitude sectors. The latitudinal variations for different months are presented in Fig. 3, with each curve depicting the latitude variations in different longitudinal sectors. Throughout the year, the latitude variation in AOD is large in the Northern Hemisphere compared to that in the Southern Hemisphere, and also shows significant seasonal variations. A sharp gradient in AOD is observed especially north of $5^{\circ} \mathrm{N}$. Between the equator and $15^{\circ} \mathrm{S}$ the latitudinal gradient is very small and the AOD values remain fairly constant in this region considering the associated uncertainties. South of $15^{\circ} \mathrm{S}$, on average, the AOD shows a small decrease with an increase in latitude except during the winter months. Though the latitude variation in AOD is almost similar in the East Arabian Sea and Bay of Bengal sectors during the November to May period, a significant difference is observed in these sectors during June-August.

Over the WAS sector, the highest latitude gradient in AOD is observed during June -August at north of about $5^{\circ} \mathrm{N}$, with the mean AOD increasing from about 0.15 to greater than 0.5 with increase in latitude. Generally, the latitude gradient is higher in the EAS sector in all the months. During the March -April period, it is significantly larger than those in the other sectors. During May, the latitudinal gradients in all five sectors are more or less similar. The gradient in the EAS sector starts increasing from June and reaches its maximum by July. Except during the June to September period, the latitudinal gradient in the CAS sector is generally smaller than that in the other Arabian Sea sectors. In the CAS and EAS sectors the gradient increases drastically in July and becomes more or less the same as that for the western sector. While the gradients in the three Arabian Sea sectors are almost the same in July and start decreasing from August, those over the Bay of Bengal remain more or less the same as that observed in May. It is quite interesting to note that the latitudinal gradients in the two Bay of Bengal sectors are low during the June-September period and build up slowly from October, reaching maximum during the March-April period. The latitude gradient is least in all the sectors during the OctoberNovember period. In the East Bay of Bengal sector, a peak in the AOD is observed around $15^{\circ} \mathrm{N}$ predominantly in the Asian dry season, with relatively larger values in March. This feature is also observable in the AOD maps shown in Fig.1, close to the Myanmar coast, associated with a localized high value of AOD, which can be attributed to a localised advection of aerosols from the adjacent continent. It may be noted that in this longitude sector beyond $15^{\circ} \mathrm{N}$, the oceanic region is relatively small and no AOD will be available over the continents. As such, data availability will also be poor beyond $15^{\circ} \mathrm{N}$ in this sector, especially during the monsoon period. In such cases the curve for this sector is terminated at $15^{\circ} \mathrm{N}$.

Another important feature observed in this figure is a small peak in AOD appearing around $15^{\circ} \mathrm{N}$ in the West Bay of Bengal sector during the June-July period. This feature is also observable from AOD maps presented in Fig. 1. On examining the wind field in this figure it can be seen that during the Asian dry period the flow is directed along the east coast of the Indian continent which turns to west in the Peninsular region around $15^{\circ} \mathrm{N}$ and the AOD in this region decreases from $20^{\circ} \mathrm{N}$ towards south in the direction of the flow. With the onset of monsoon in the west coast of the Indian peninsula in June the flow pattern changes drastically. The wind is directed across the Indian Peninsula. The high AOD region near the east coast on peninsular India extending to Head of Bay of Bengal (HBoB) recedes north, leaving a small portion around $15^{\circ} \mathrm{N}$, which subsequently spreads towards the east in June along the wind direction. With the onset of southwest monsoon, though the source strength over central India decreases and the wet removal becomes more efficient, resulting in a drastic decrease in the strength of the continental aerosol plume, the east-coast of the Indian peninsula remains more or less dry because of scanty rain fall in this region, which picks up only towards the end of the southwest monsoon period (September). Thus, the east coast of the Indian peninsula remains fairly dry during June and strong westerly wind drives the aerosol from the continent over to $\mathrm{BoB}$, contributing to the peak in AOD around $15^{\circ} \mathrm{N}$ (Fig. 3) in the EBoB sector (this feature is observable in Fig. 1 also). This peak disappears almost completely by September. The latitudinal gradient in the two BoB sectors is very small during the September to November period, as there is no significant advection of continental aerosols over to the $\mathrm{BoB}$ in this period of the year.

This study thus clearly brings out the fact that the latitudinal gradients over the northern parts show significant variability with longitude and is strongly influenced by the nature of advection from the adjoining continental landmasses. Apart from this, a small increase in AOD is seen south of the equator up to about $15^{\circ} \mathrm{S}$ in all five sectors, with the highest AOD occurring around $15^{\circ} \mathrm{S}$ during the period JuneSeptember (with peak values around 0.13). This increase is less pronounced during the Asian dry season, and can be attributed to increased in-situ production of sea-salt aerosols through strong surface winds. A peak in AOD appearing around $10^{\circ} \mathrm{S}$ in the two longitude sectors over the Bay of Bengal (WBoB and EBoB) during the September-December period is due to increased aerosol loading caused by forest fires occurring in the Indonesian region associated with increased dryness (Parameswaran et al., 2004).

As can be seen from Fig. 3, the latitude variations in AOD are well pronounced in the Northern Hemisphere. In order to depict the seasonal variations in latitude gradient, the mean gradient in each of the five longitude sectors are estimated for each month through linear regression. This analysis is performed for the entire latitude region $\left(20^{\circ} \mathrm{S}\right.$ to $\left.20^{\circ} \mathrm{N}\right)$, as well as for the Northern Hemisphere in the latitude region 0 to $20^{\circ} \mathrm{N}$, where the gradients are largest. The month-tomonth variations of the AOD gradient (per degree latitude) thus obtained for the two cases are presented in Figs. 4a and $b$, respectively. Though the gross seasonal patterns of the latitude gradients in Figs. 4a, b are similar, the variations are 


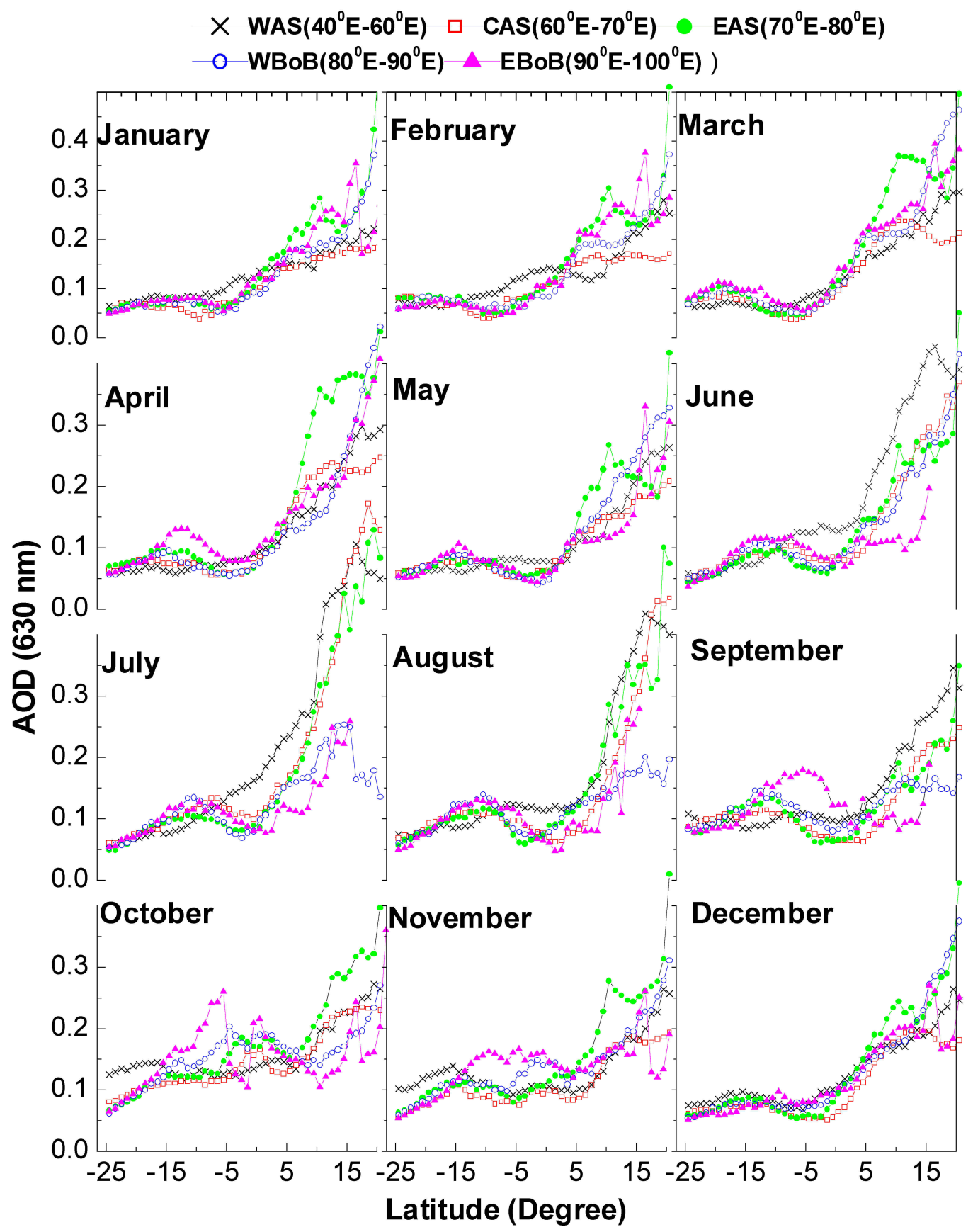

Fig. 3. Monthly mean latitudinal variation of AOD averaged for the period of 1996-1999, 2001-2003 in the longitudinal sectors of the West Arabian Sea (WAS; $40^{\circ} \mathrm{E}$ to $60^{\circ} \mathrm{E}$ ), Central Arabian Sea (CAS; $60^{\circ} \mathrm{E}$ to $\left.70^{\circ} \mathrm{E}\right)$, East Arabian Sea (EAS; $70^{\circ} \mathrm{E}$ to $\left.80^{\circ} \mathrm{E}\right)$, West Bay of Bengal (WBoB; $80^{\circ} \mathrm{E}$ to $\left.90^{\circ} \mathrm{E}\right)$ and East Bay of Bengal $\left(\mathrm{EBoB} ; 90^{\circ} \mathrm{E}\right.$ to $\left.100^{\circ} \mathrm{E}\right)$.

more pronounced in Fig. 4b. The absolute value of the gradient in Fig. $4 \mathrm{~b}$ is also significantly larger (about twice) than the corresponding value in Fig. 4a. Seasonal variations of the latitude gradient in AOD in different longitude sectors are clearly observable in Fig. 4. The latitude gradient in the two BoB sectors is very small during September and October (nearly zero in EBoB sector). The gradient in all five sectors show a peak during the March-April period when the AOD value over the Indian continent shows also a maximum (Moorthy et al., 1993; Vinoj et al., 2004). A sharp increase in gradient is observed in the Arabian Sea sectors during the July-August period while this feature is totally absent in the 


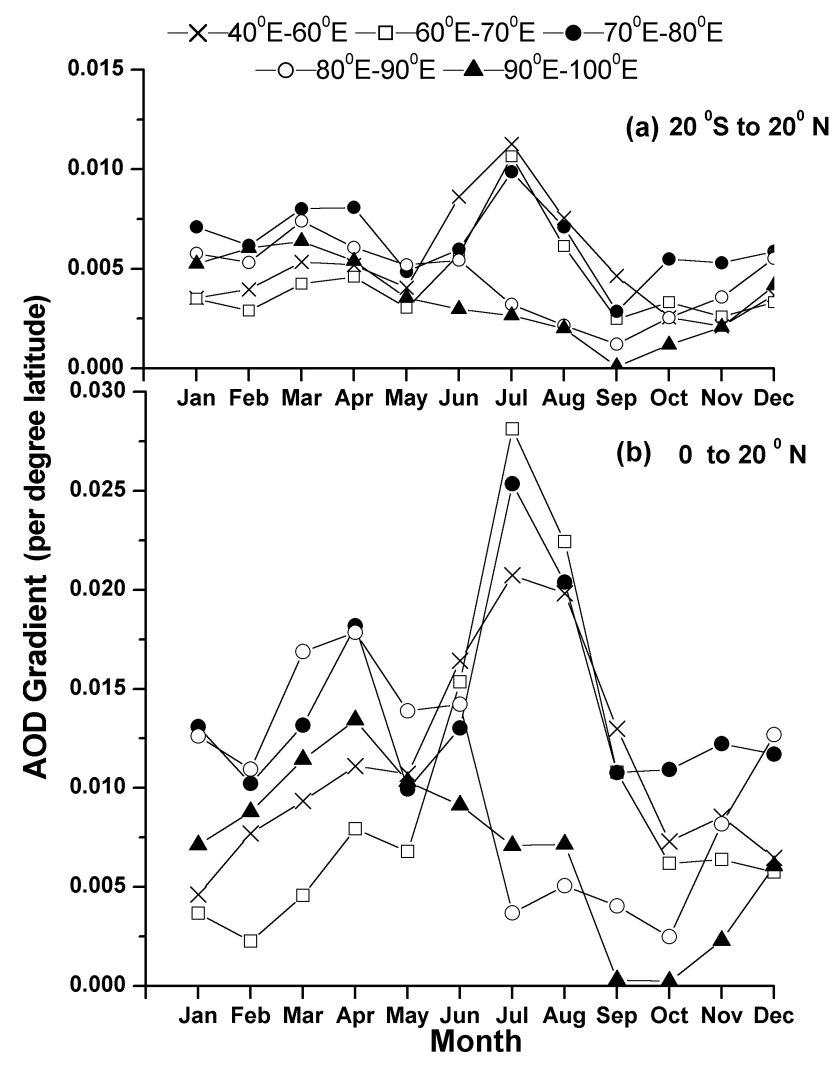

Fig. 4. Month-to-month variation of latitude gradient in AOD observed by linear regression of latitude variation in the West Arabian Sea (WAS; $40^{\circ} \mathrm{E}$ to $60^{\circ} \mathrm{E}$ ), Central Arabian Sea (CAS; $60^{\circ} \mathrm{E}$ to $70^{\circ} \mathrm{E}$ ), East Arabian Sea (EAS; $70^{\circ} \mathrm{E}$ to $80^{\circ} \mathrm{E}$ ), West Bay of Bengal (WBoB; $80^{\circ} \mathrm{E}$ to $\left.90^{\circ} \mathrm{E}\right)$ and East Bay of Bengal (EBoB; $90^{\circ} \mathrm{E}$ to $100^{\circ} \mathrm{E}$ ) for the entire latitude region of $20^{\circ} \mathrm{S}$ to $20^{\circ} \mathrm{N}$ (a) and for the Northern Hemisphere $0-20^{\circ} \mathrm{N}$ (b).

BoB sectors. This is mainly contributed by the high AOD over the Arabian Sea during the summer monsoon season.

It would sometimes be more meaningful to present the latitude distribution in terms of a "scale distance" rather than a linear gradient, in quantifying the spatial distribution of AOD. The scale distance is defined here as the distance at which the AOD decreases by a factor of $1 / e$ from its initial value around $20^{\circ} \mathrm{N}$ (near the continent) along each longitude sector across the latitude. For this it is necessary to examine the slope of a logarithmic regression between AOD and latitude. The regression analysis is performed between $\log (\mathrm{AOD})$ and latitude at different longitude sectors and the resulting slopes are obtained. The scale distance is estimated by multiplying the reciprocal of the regression slope by $110 \mathrm{~km}$, which approximately corresponds to the horizontal distance covered by $1^{\circ}$ latitude in the tropics. The monthto-month variation of scale distance in different longitude sectors thus obtained is presented in Figs. 5a and 5b, respectively, for the $20^{\circ} \mathrm{S}$ to $20^{\circ} \mathrm{N}$ and 0 to $20^{\circ} \mathrm{N}$. The scale

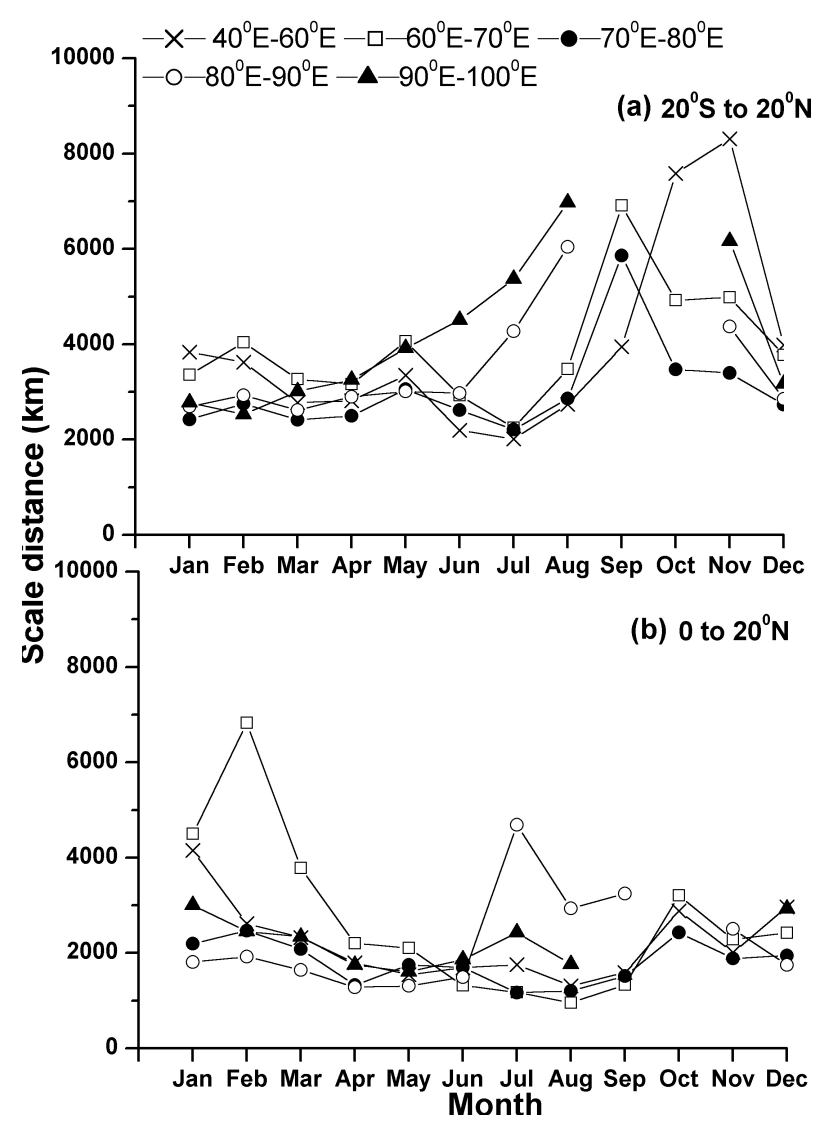

Fig. 5. Month-to-month variation of "scale distance" (see text for details) in different longitude sectors in the West Arabian Sea (WAS; $40^{\circ} \mathrm{E}$ to $60^{\circ} \mathrm{E}$ ), Central Arabian Sea (CAS; $60^{\circ} \mathrm{E}$ to $70^{\circ} \mathrm{E}$ ), East Arabian Sea (EAS; $70^{\circ} \mathrm{E}$ to $80^{\circ} \mathrm{E}$ ), West Bay of Bengal (WBoB; $80^{\circ} \mathrm{E}$ to $90^{\circ} \mathrm{E}$ ) and East Bay of Bengal $\left(\mathrm{EBoB} ; 90^{\circ} \mathrm{E}\right.$ to $100^{\circ} \mathrm{E}$ ) for the entire latitude region $20^{\circ} \mathrm{S}$ to $20^{\circ} \mathrm{N}$ (a) and for the Northern Hemisphere $0-20^{\circ} \mathrm{N}$ (b).

distance is low when the latitude gradient in AOD is large and vice versa. In the Northern Hemisphere, except over the mid Arabian Sea sectors, in general, the scale distance is around 2000-3000 km during January which decreases to $<2000 \mathrm{~km}$ by August. This is in agreement with the value of scale distance derived from spatial variation of aerosol optical depth measured using solar radiometer on different cruises over the Arabian Sea and Indian Ocean (Satheesh et al., 1998). The scale distances in the three Northern Hemispheric Arabian Sea sectors increases to $>3000 \mathrm{~km}$ during the October- December period. During September-November the scale distance is very large in the BoB sectors (as seen from Fig. 3 there is no pronounced latitude variation in these sectors during this period) and hence is not presented in this figure. On examining the scale distance in Fig. 5 a $\left(20^{\circ} \mathrm{S}\right.$ to $\left.20^{\circ} \mathrm{N}\right)$ the value lies in the range of 2000 to $8000 \mathrm{~km}$ in all the longitude regions. Due to very small AOD gradients prevailing in the Southern Hemisphere the overall scale distance is langer than that in the Northern Hemisphere. 


\section{Interannual variations in the mean AOD during 1996-2003}

As seen in the earlier studies (Nair et al., 2003; Rajeev et al., 2004) the monthly mean spatial pattern of prevailing lower tropospheric circulation and hence the aerosol transport show significant similarities during the period November to January (first half of the Asian dry season, hereafter referred to as D1), February to April (second half of the Asian dry season, hereafter referred to as D2), and June to September (Asian summer monsoon season, hereafter indicated by $\mathrm{SM})$. This is also evident from the circulation pattern at the 850-hpa level presented in Fig. 1. Hence, the AOD data are grouped into three seasons and the seasonal mean AOD during each year of observation is obtained. The intra-season months of May and October are not included in estimating the seasonal mean AODs mainly because of the fact that the circulation pattern changes from one form to other in the month and hence could not be included in either of the two. Figure 6 shows the regional distribution of the seasonal mean AOD during D1, D2 and SM for different years during the study period. The geographical structure of the seasonal mean AOD distributions (such as the locations of low and high AOD) is strikingly similar during the same season in different years, though significantly large interannual variability in AOD is observable. This variability is largest during the second half of the Asian dry season (February-April), particularly over the southeast Arabian Sea and north Bay of Bengal near the Indian peninsula. The seasonal mean AOD values during the February-April period of 1999 is about 1.5 to 2 times larger than the corresponding values during all the other years. Though this enhanced aerosol loading is largest around the Indian peninsula, such high AOD values are also observed in the eastern parts of Bay of Bengal and the coastal regions of Arabia. It is also interesting to note that the AOD values are considerably lower in these regions for the same season in the previous and subsequent years. The maximum observed interannual variability (minimum to maximum value) in AOD is $\sim 0.25$ in the southeast Arabian Sea and northwest Bay of Bengal near the Indian peninsula and in Southeast Asia during the February-April period. This variability is less than 0.2 in all the seasons over the West Arabian Sea. Interannual variability in the seasonal mean AOD is a minimum during the first half of the Asian dry period (November-January), and is less than 0.1 over most of the areas in the Northern Hemisphere. During the Asian summer monsoon season (June-September), the seasonal mean AOD ranges from $\sim 0.45$ to 0.6 near the western Arabian Sea close to Arabia, a zone of largest aerosol loading over the study region. The interannual variability in AOD in this region is less than 0.2. Though this variability is relatively high in the eastern and central Arabian Sea during the summer monsoon, it must be remembered here that this region is mostly cloudy during the Asian summer monsoon season (with seasonal mean fractional cloudiness between $70 \%$ and $90 \%$ ). The AOD data during the summer monsoon period in this region is only one-fourth of that available in other regions and also in the same region during the other seasons and hence should be treated cautiously.

The observed interannual variability in AOD can be attributed to the interannual variability in the rainfall, tropospheric circulation and surface wind speed. Over the Bay of Bengal, the seasonal mean AOD values are less than 0.3 during SM and the maximum variability is less than $\sim 0.15$. Over the Southern Hemisphere Indian Ocean, these values are less than 0.2 in all seasons, except during the second half of 1997 when the tropical Indian Ocean was under the influence of an intense aerosol plume originating from the Indonesian forest fires (Parameswaran et al., 2004) and the interannual variability is less than $\sim 0.05$. This aspect is further examined in detail by taking the mean AODs over a relatively small region bounded by $5^{\circ} \times 5^{\circ}$ in latitude-longitude width. The regions so selected are: Coastal Arabia (CA: $15^{\circ} \mathrm{N}$ to $20^{\circ} \mathrm{N}, 58^{\circ} \mathrm{E}$ to $63^{\circ} \mathrm{E}$ ), Southeast Arabian Sea (SEAS: $7^{\circ} \mathrm{N}$ to $12^{\circ} \mathrm{N}, 70^{\circ} \mathrm{E}$ to $75^{\circ} \mathrm{E}$ ), Head Bay of Bengal (HBoB: $15^{\circ} \mathrm{N}$ to $20^{\circ} \mathrm{N}, 85^{\circ} \mathrm{E}$ to $90^{\circ} \mathrm{E}$ ), South East Bay of Bengal (SEBoB: $0^{\circ}$ to $5^{\circ} \mathrm{N}, 90^{\circ} \mathrm{E}$ to $95^{\circ} \mathrm{E}$ ) and Southern Hemisphere Indian Ocean (SHIO: $15^{\circ} \mathrm{S}$ to $20^{\circ} \mathrm{S}, 85^{\circ} \mathrm{E}$ to $90^{\circ} \mathrm{E}$ ). The temporal variations in the seasonal mean AOD during the 3 seasons discussed above (D1, D2, and SM) are presented in Fig. 7. A systematic variation in AOD by month is clearly seen in Fig. 7 over CA, SEAS and HBoB. Over Coastal Arabia maximum AOD is observed in SM and minimum in D1. Over the southeast Arabian Sea and Head Bay of Bengal maximum AOD is observed during D2 and minimum during SM. The maximum interannual variability is observed in SEAS during D2, when the seasonal mean AOD varies from 0.19 to 0.42 , with the highest values during 1999 . The interannual variability over SEAS is least during D1 when the AOD varies only between 0.16 and 0.22 . During the summer monsoon the interannual variability over SEAS is larger than that during the first half of the Asian dry season (D1) when the mean AOD varied from 0.12 to 0.27 . The interannual variability over the $\mathrm{HBoB}$ is also a maximum during D2 with seasonal mean AOD varying between 0.24 and 0.39. Highest values of AOD over HBoB are observed during D2 of 1999 and 2001. Its interannual variability over HBoB during D1 is very small, with values generally ranging from 0.20 to 0.27 . Except for the very small values of 0.03 encountered in 1996 and 0.07 in 2001, the interannual variation in the mean AOD is very small during the summer monsoon season over this region. Over the Coastal Arabia, the largest interannual variability is observed during the Asian summer monsoon season (mean AOD ranges from 0.34 to 0.47 ) and the minimum variability during D1 (mean AOD ranging from 0.14 to 0.18). During D2 the interannual variability in AOD over CA is from 0.11 to 0.23 . Another interesting feature observed in the interannual variations of AOD over CA is the long period oscillation (with period of around two years). This aspect however, requires a detailed study and hence is not discussed here. The interannual variability in AOD over SE$\mathrm{BoB}$ is maximum during $\mathrm{D} 1$ with values ranging from 0.04 to 0.25 . The peak over SEBoB is more prominent during D1 of 1997 followed by a secondary peak in D2 of 1998, which is 


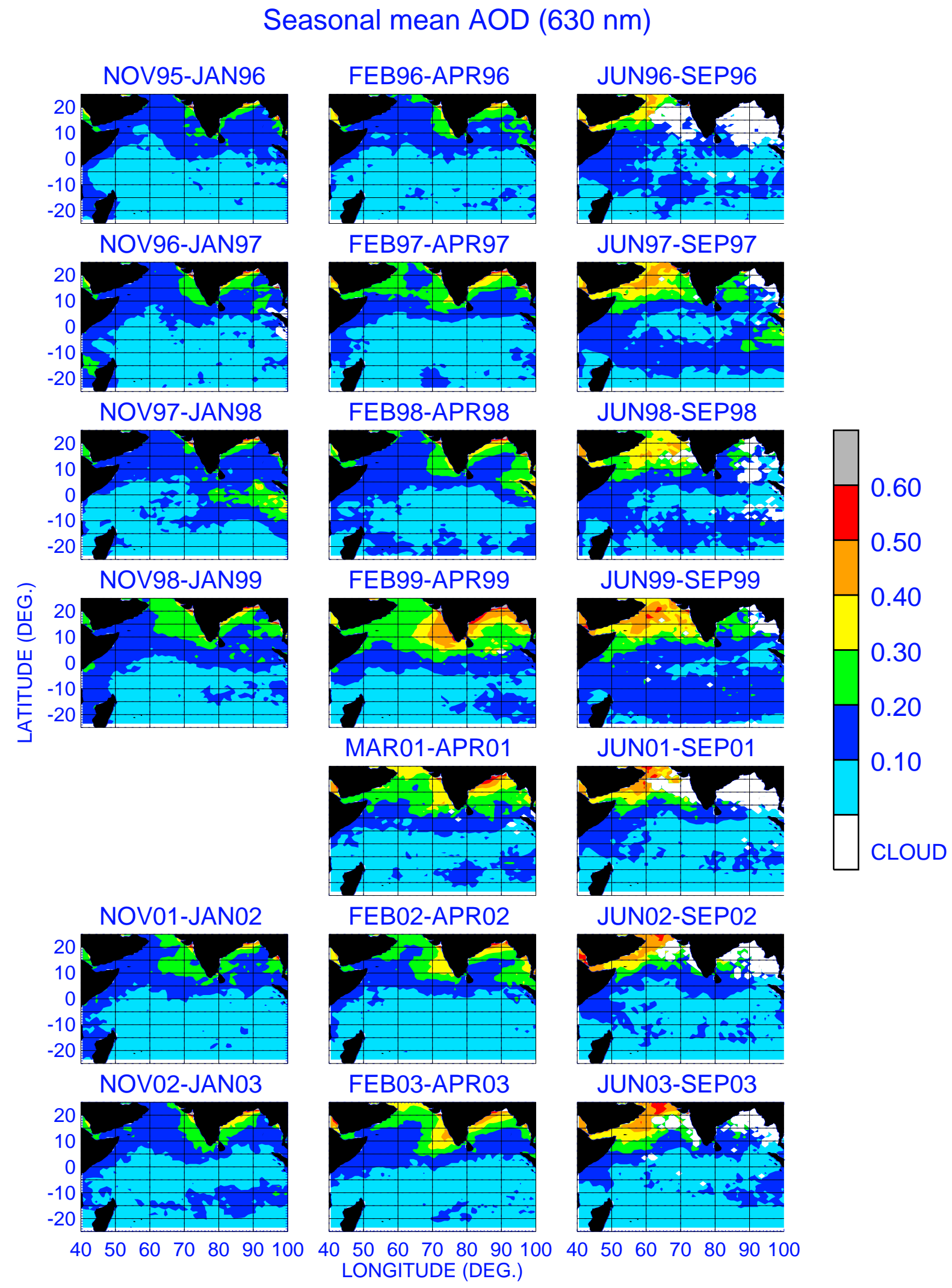

Fig. 6. Regional distribution of mean AOD for the three seasons; first half of the Asian dry season, D1 (November-January), second half of the Asian Dry season D2 (February-April), Asian summer monsoon season, SM (June-September) in different years during the study period. 
mainly due to the high aerosol loading caused by the Indonesian forest fires. The interannual variability in AOD over the SHIO is almost insignificant (ranges from 0.07 to 0.12 ), considering the associated uncertainties in the derived AOD values.

\section{Discussion}

Aerosol distribution and transport over the oceanic areas around the Indian subcontinent delineated in the earlier studies, using the satellite and in-situ observations along with atmospheric circulation obtained from models (Rajeev et al., 2000; Rasch et al., 2001; Verver et al., 2001; Leon et al., 2001; Li and Ramanathan, 2002; Tahnk and Coakley, 2002; Nair et al., 2003; Rajeev et al., 2004), have shown the influence of the transport of aerosols from the Indian subcontinent, southeast Asia and Arabia into the oceanic areas around the Indian subcontinent during the Asian dry period through the lower tropospheric northerly (northeasterly or northwesterly) winds. However, in addition to atmospheric circulation, the altitude of the aerosol plume and the aerosol residence time in the atmosphere determines the horizontal extent of the transport of aerosols from their source regions. Furthermore, the surface wind speed controls the production of sea-salt aerosols (Erickson et al., 1986). The lidar observations show that the aerosol abundance is observed below about $4 \mathrm{~km}$ in the Southeast Arabian Sea region throughout the year (Ansmann et al., 2000; Muller et al., 2001).

The influence of atmospheric circulation on the horizontal distribution of aerosols is clearly observable in Fig. 1, which shows the monthly mean wind vector at the 850-hpa level averaged for the 1996-2003 period obtained from the NCEPNCAR reanalysis (Kalnay et al., 1996), along with the spatial distribution of AOD. The general features of the atmospheric circulation pattern during the same month are similar in the lower tropospheric levels. This is clear from the comparison of the circulation pattern shown in Fig. 1 with that of Fig. 8, which shows the mean circulation pattern during 1996-2003 at 925- and 700-hpa levels in November, February, June and September. However, at the higher altitudes the wind pattern shows deviations. The lower tropospheric wind in the Northern Hemisphere has a prominent northerly component directed away from the continent and towards the oceanic areas during the November-April period. Over the Southern Hemisphere, the flow is dominantly easterly or southeasterly, and meets with the flow from the Northern Hemisphere at the ITCZ. Throughout the year, the surface wind speed is greater than $\sim 6 \mathrm{~ms}^{-1}$ in a latitude band with a width of about $10^{\circ}$ to $15^{\circ}$ in the Southern Hemisphere, between $30^{\circ} \mathrm{S}$ and $5^{\circ} \mathrm{S}$. The wind speed is highest in September $\left(\sim 10 \mathrm{~ms}^{-1}\right)$ and lowest between January-February $\left(\sim 7 \mathrm{~ms}^{-1}\right)$. However, the wind direction in this region is predominantly easterly throughout the year. The actual position of the highest wind speed region undergoes an annual variation, from $\sim 15^{\circ} \mathrm{S}$ during July-August to $\sim 20^{\circ} \mathrm{S}$ in February. The ITCZ positioned south of the equator between $5^{\circ} \mathrm{S}$ and $15^{\circ} \mathrm{S}$ in the

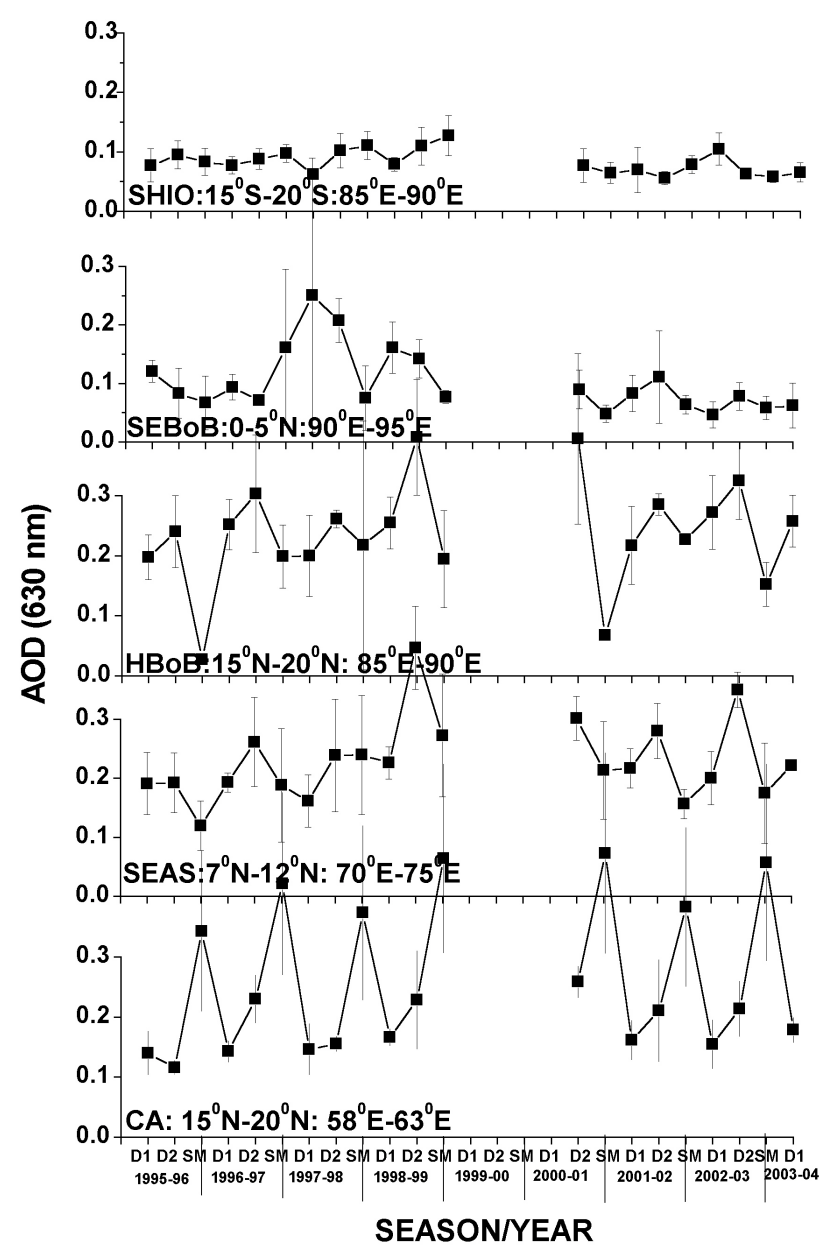

Fig. 7. Variation of seasonal (D1, D2 and SM) mean AOD in different years in five selected regions; Coastal Arabia (CA: $15^{\circ} \mathrm{N}$ to $20^{\circ} \mathrm{N}, 58^{\circ} \mathrm{E}$ to $63^{\circ} \mathrm{E}$ ), Southeast Arabian Sea (SEAS: $7^{\circ} \mathrm{N}$ to $12^{\circ} \mathrm{N}, 70^{\circ} \mathrm{E}$ to $\left.75^{\circ} \mathrm{E}\right)$, Head Bay of Bengal (HBoB: $15^{\circ} \mathrm{N}$ to $20^{\circ} \mathrm{N}, 85^{\circ} \mathrm{E}$ to $90^{\circ} \mathrm{E}$ ), South East Bay of Bengal (SEBoB: $0^{\circ} \mathrm{N}$ to $5^{\circ} \mathrm{N}, 90^{\circ} \mathrm{E}$ to $95^{\circ} \mathrm{E}$ ) and Southern Hemisphere Indian Ocean (SHIO: $15^{\circ} \mathrm{S}$ to $20^{\circ} \mathrm{S}, 85^{\circ} \mathrm{E}$ to $90^{\circ} \mathrm{E}$ ).

$65^{\circ} \mathrm{E}$ to $80^{\circ} \mathrm{E}$ longitude region (Nair et al., 2003) during the Asian dry period shifts to $20^{\circ} \mathrm{N}$ to $25^{\circ} \mathrm{N}$ during the summer monsoon season. The highest annual variation in the wind (speed and direction) is observed in the Northern Hemisphere, particularly in the west Arabian Sea (near Somalia) and Bay of Bengal.

During the Asian dry season, the lower tropospheric wind has a dominating northerly component. Though the overall wind speed is less, the residence time of aerosols in the atmosphere is expected to be larger ( $\sim 10$ days) in the Northern Hemisphere during the Asian dry season (Lelieveld et al., 2001), due to the large-scale dryness prevailing in the atmosphere, aiding the transport of continental aerosols over to the Arabian Sea and Bay of Bengal (Nair et al., 2003). However, the area occupied by the high AOD region during the Asian dry period is significantly smaller than that during 


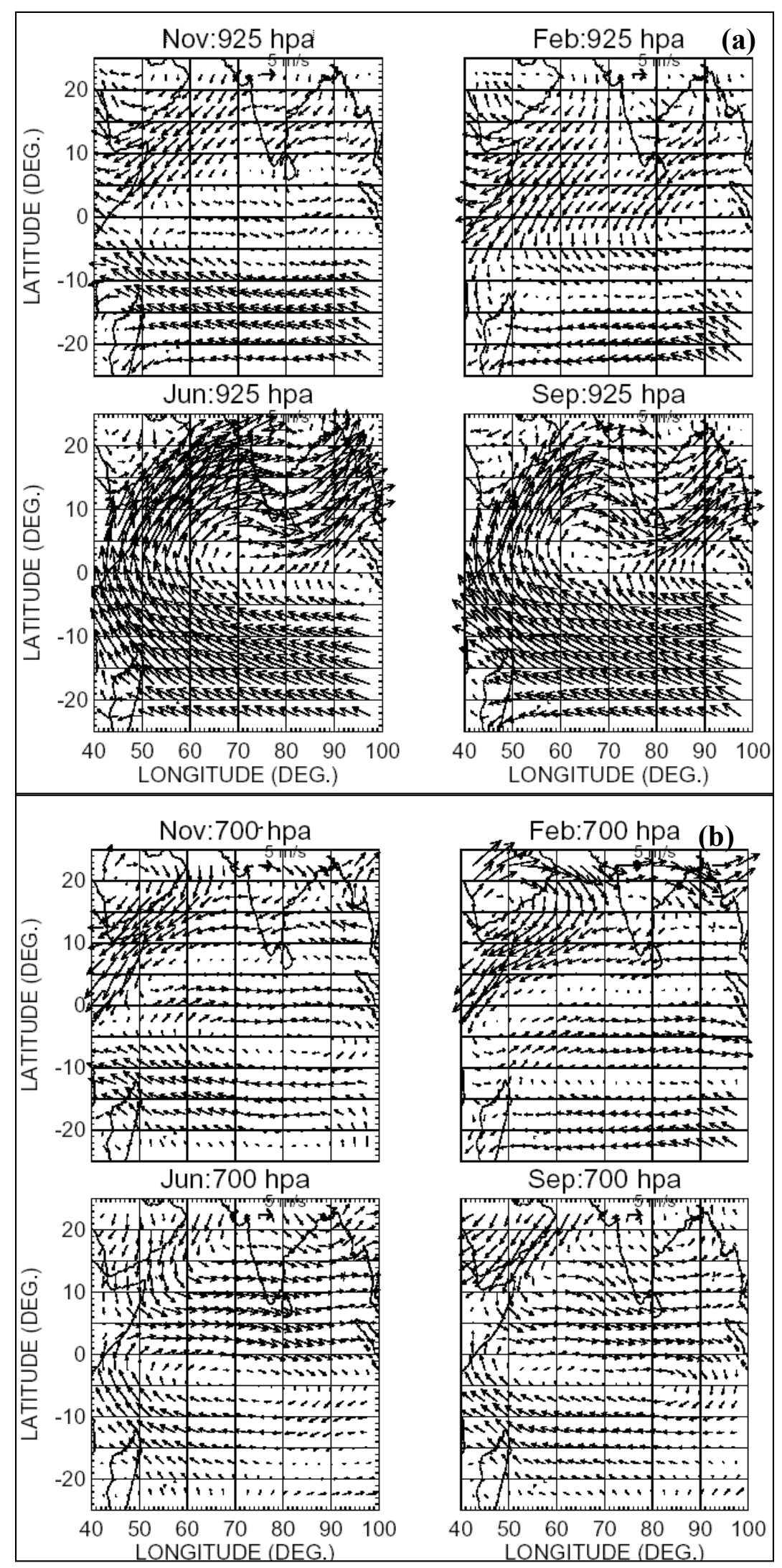

Fig. 8. The monthly mean wind vectors for four representative months November, February, June and September, at the 925-hpa level (a) and the 700-hpa level (b), averaged for different years during the study period. 


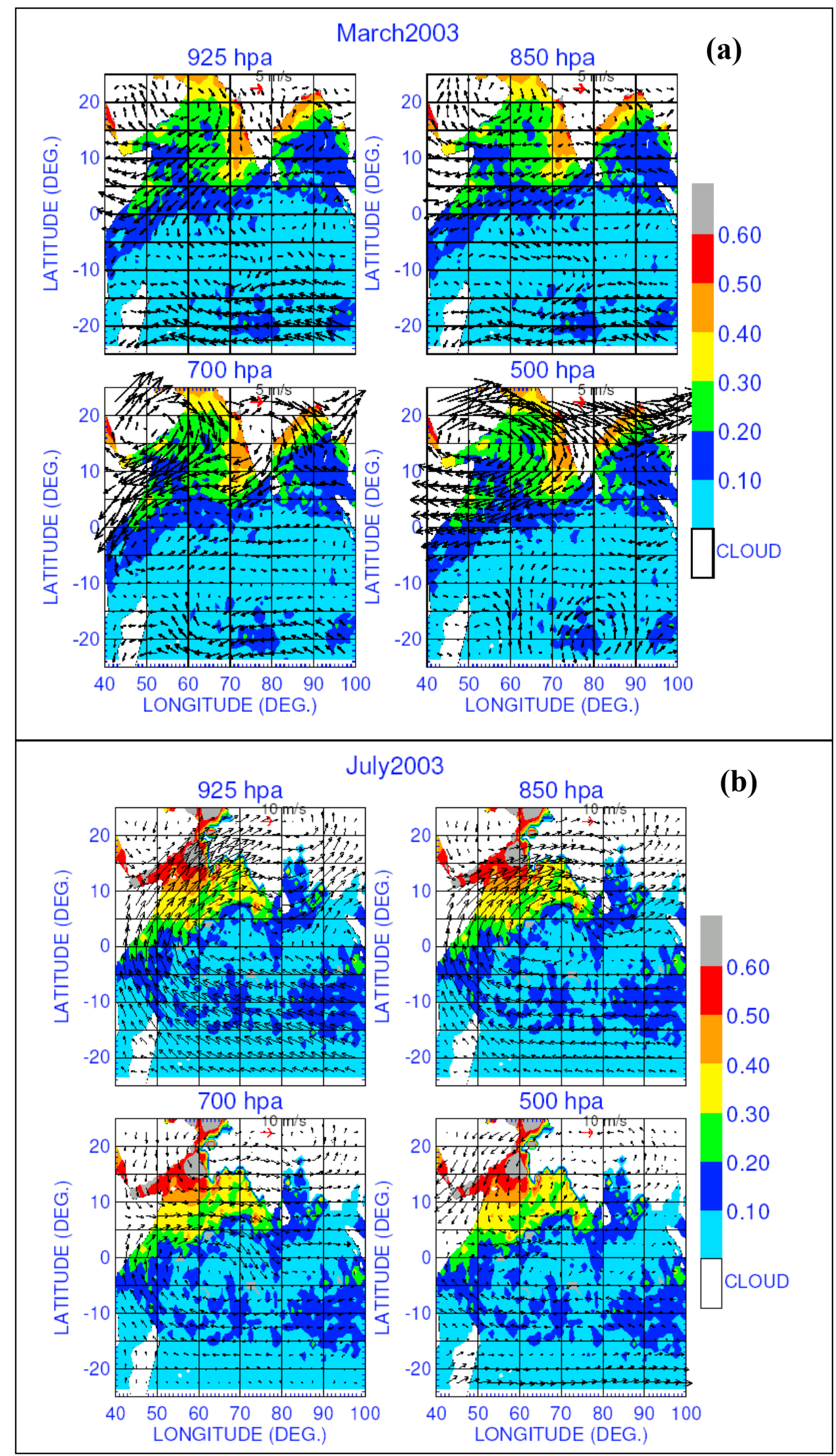

Fig. 9. Regional maps of mean AOD in March 2003, along with wind vector at different pressure levels (925 hpa , $850 \mathrm{hpa}, 700 \mathrm{hpa}$ and 500 hpa) in March 2003 (a) and in July 2003 (b). 
the summer monsoon period and is mainly observed adjacent to the continental areas in the Northern Hemisphere. The largest spatial gradients in AOD are observed over the southeast Arabian Sea sector during the Asian dry period (note the AOD distribution at Southeast Arabian Sea during February-April shown in Fig. 1 and Fig. 6) compared to the summer monsoon period. The AOD decreases away from the continent in the direction of the lower tropospheric wind in the southeast Arabian Sea. Similarly, near the Head Bay of Bengal a cyclonic circulation is observable in the wind field at the 925-hpa level and the AOD decreases away from the continent in the direction of the wind. Figure 9a shows the monthly mean AOD map of March 2003 along with the wind vectors at different pressure levels; 925, 850, 700, and $500 \mathrm{hpa}$, respectively, corresponding to approximately 0.8 , $1.5,3$ and $5 \mathrm{~km}$. As is seen in this figure the wind features at the $925 \mathrm{hpa}$ level continues to persist up to around $700 \mathrm{hpa}$. Above this level they start departing significantly. The observed features in AOD would also have been influenced more by the aerosol loading in the lower troposphere, since the maximum contribution to the columnar AOD is from the altitudes below about $4 \mathrm{~km}$ (e.g. Ansmann et al., 2000). If we attribute advection of the continental layer for increased AOD, the maximum should occur where the wind converges and it should decrease in the direction of wind away from the convergence zone or in the direction of a divergence. Then from Fig. 9a we see that such a condition exists in the SEAS and $\mathrm{HBoB}$ sectors at altitudes $\leq 3 \mathrm{~km}$.

It would be interesting to examine the possible sources of aerosols contributing to the AOD in the altitude region $\leq 3 \mathrm{~km}$. For this the possible air-mass advections in the SEAS and $\mathrm{HBoB}$ during the Asian dry period are examined. Figures $10 \mathrm{a}-\mathrm{d}$ show the 7-day back trajectories ending at $12^{\circ} \mathrm{N}$, $70^{\circ} \mathrm{E}$ over the SEAS at 4 different levels $(0,1.0,2.0$ and $4.0 \mathrm{~km}$ above the surface) for all days in March 2003, obtained from the NOAA-ARL - HYSPLIT transport dispersion model (global reanalysis using archived CDC data set) (Draxler and Rolph, 2003; Rolph, 2003). The colors in each trajectory indicate the altitudes of the air parcel at each location along its path. Similarly, Figs. 10e-h show all the 7day back trajectories ending at $18^{\circ} \mathrm{N}, 90^{\circ} \mathrm{E}$ over the $\mathrm{HBoB}$ at four altitudes $0,1,2$ and $4 \mathrm{~km}$. On examining the trajectories near the surface over the SEAS region (Fig. 10a), most of the air parcels reaching here remain close to the surface and originate near the coastal regions of the north Arabian sea. In addition to this, for about 5-6 days in March 2003, air parcels originating from higher altitudes in the arid region north of $20^{\circ} \mathrm{N}$ sink near the coast and reach the observation point. However, in almost all the cases, the trajectories were lying below $700 \mathrm{~m}$ at the north Arabian sea and the ability of such trajectories to bring aerosols to the end location of SEAS is doubtful, since the aerosol residence time at $<1 \mathrm{~km}$ is expected to be less than $2-3$ days. At $1 \mathrm{~km}$ there is also significant number of trajectories originating from the coastal regions of the northwest and northeast Arabian sea around $1 \mathrm{~km}$, reaching the study region. A few trajectories originating from higher altitudes over the arid regions in the northwest (Arabian regions) and from the east (crossing the south Peninsular India) also reach $1 \mathrm{~km}$. Most of the trajectories reaching $2 \mathrm{~km}$ originate from the Indian subcontinent either from the same level or above. Considering the $4 \mathrm{~km}$ altitude, most of the trajectories reaching this point originate from higher altitudes of Arabia ( $>4 \mathrm{~km}$ ) and often cross the eastern Arabian Sea and western parts of the Indian subcontinent before reaching SEAS. Figure 10 shows that for altitudes below $\sim 3 \mathrm{~km}$ most of the air parcels reaching this point originate from adjacent oceanic regions or near to the continental regions of the Indian peninsula. The air trajectories reaching above this altitude originate from higher altitudes $(>4 \mathrm{~km})$ over the arid regions, which are expected to have smaller aerosol loading. Examining the wind field in Fig. 9a in lower altitudes there is a convergence in this region, and at altitudes above $\sim 1.5 \mathrm{~km}$ the AOD gradient in the plume is along the wind direction, up to $\sim 3 \mathrm{~km}$ (corresponding to $\sim 700 \mathrm{hpa}$ ). This pattern starts deviating at higher altitudes. Since the wind speeds near the surface are low the in-situ production of sea-salt aerosols is relatively small and hence most of the aerosols responsible for the observed high AOD over the SEAS during the Asian dry seasons would have been contributed by advection. These features indicate that the advecting aerosols from the Indian subcontinent and arid regions of Arabia would have significantly contributed to the observed aerosol plume near the west coast of the Indian Peninsula. It may also be noted in this context that the above analysis pertaining to March 2003 corresponds to an average feature for the Asian dry period and it repeats every year. But the AOD in this region was abnormally high in March 1999, which was due to anomalous behavior in the mean circulation pattern. Nair et al. (2003) studied this enhanced aerosol loading over the oceanic areas around the Indian subcontinent during the February-April period of 1999 in detail. Among the various possibilities they considered, the most probable causes for the enhanced AOD observed during 1999 were the enhanced urban air-mass flux from the Indian subcontinent through the lower troposphere into the Arabian Sea and the northern parts of Bay of Bengal and the northward position of the extended anti-cyclonic circulation over the Indian subcontinent (from $\sim 15^{\circ} \mathrm{N}$ during April 1997 and 1998 to $\sim 18^{\circ} \mathrm{N}$ during April 1999). The northward position of ITCZ (from $\sim 10^{\circ} \mathrm{S}$ during April 1997 and 1998 to $\sim 7^{\circ} \mathrm{S}$ during April 1999) and the elevated aerosol layer might also have contributed to the enhanced AOD in 1999 (Nair et al., 2003).

On examining the region of high AOD at Head Bay of Bengal, the wind directions in Fig. 9a indicates that most of the aerosol loading responsible for the observed high would have come from the altitude $\leq 3 \mathrm{~km}$. Seven-day back trajectories in Figs. 10e to 10h indicate that near the surface, significant aerosol transport occurs from the Gangetic plane, which is a region of high AOD during the Asian dry period as revealed from MODIS data (Ramanathan et al., 2001b). It may also be noted that the length of the trajectories at this level (Fig. 10e) is significantly small, which indicates a rather slow feeding of aerosol-laden air from the Indian subcontinent. At $1 \mathrm{~km}$ aerosol laden arid air from higher altitudes also 

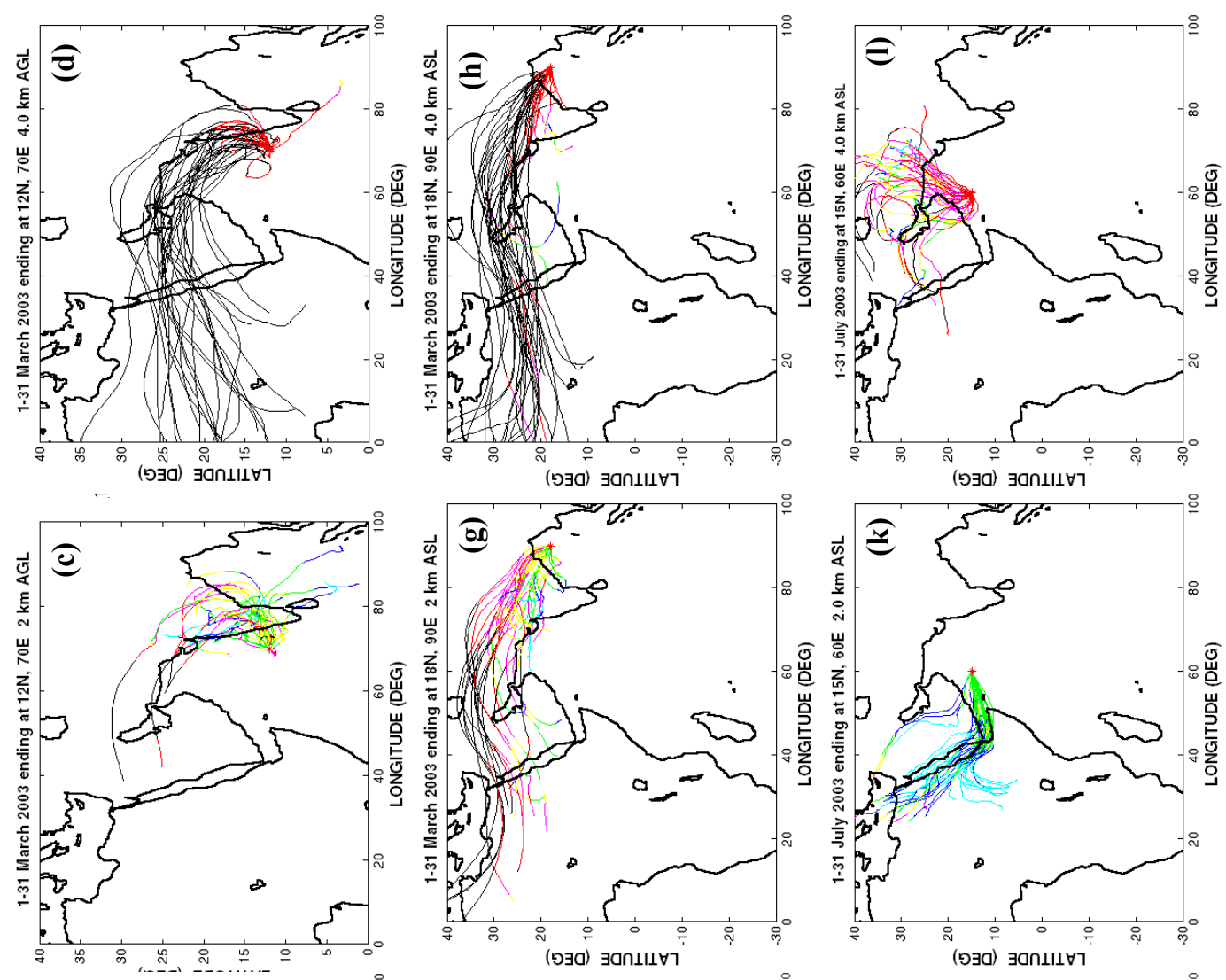

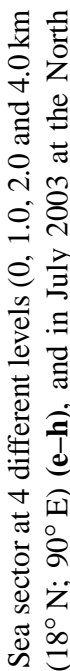
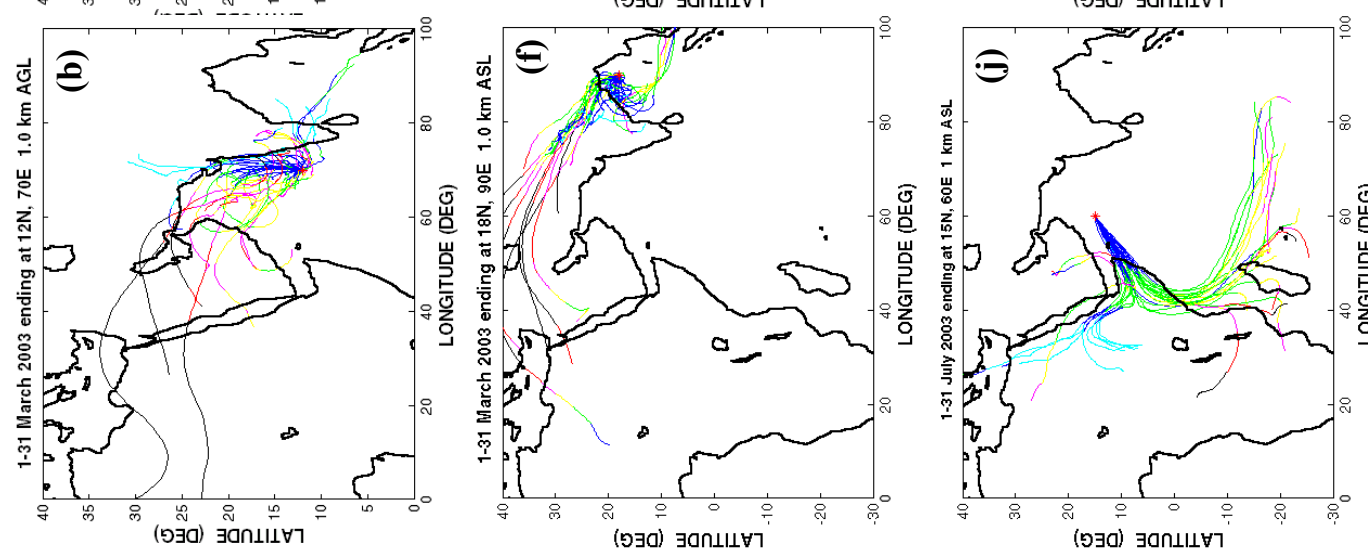

预
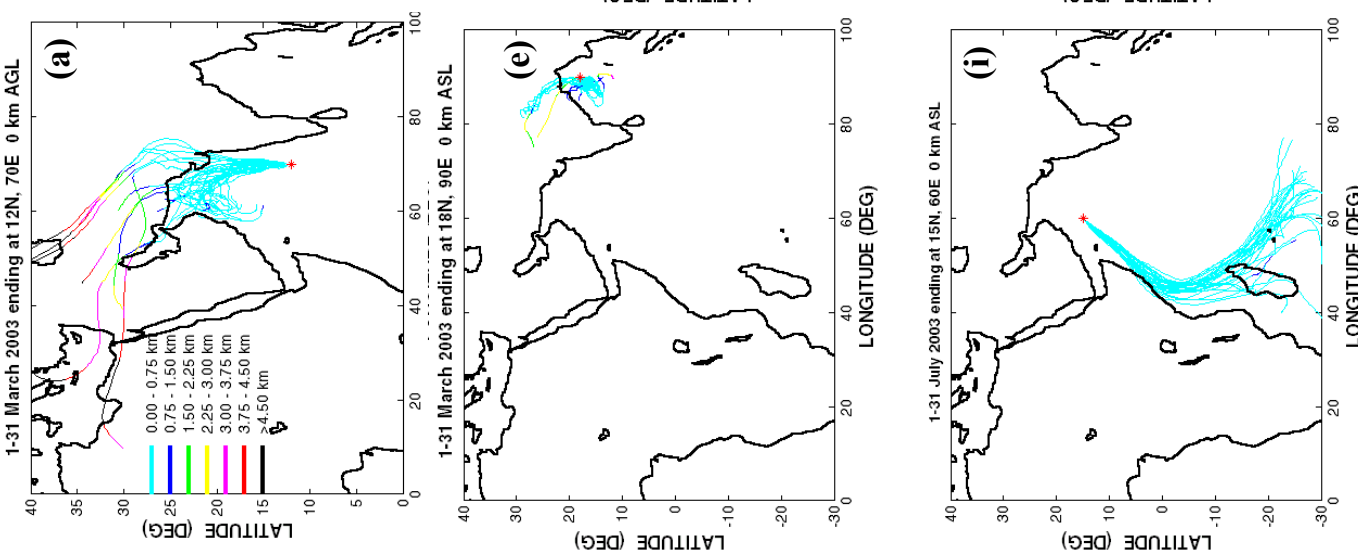

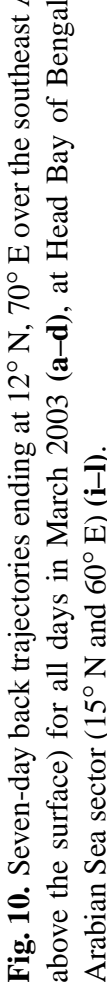


contributes to the observed aerosol burden, which includes the turbid regions over Nepal as well (Ramana et al., 2004). At 2 and $4 \mathrm{~km}$, the back trajectories are significantly long (indicating long range transport), originating from higher altitudes $(>4 \mathrm{~km})$ of arid regions of west Arabia, as well as the same altitudes over central Arabia. The air trajectories over BoB also indicate significant transport from the Southeast Asian region. A small region of high AOD observed in the east Bay of Bengal around $15^{\circ} \mathrm{N}$ (Fig. 1) has been particularly investigated by examining the air trajectories in different months. This high AOD off the Myanmar coast is observed to be mainly due to transport of continental air from Southeast Asia, as well as from Central India and Bangladesh along the east coast of the Bay. This transport is predominantly seen during the Asian dry season, when the AOD in this region is highest. During the monsoon period, as most of the air trajectories reaching this point originate from the oceanic region in the west, this feature is not prominent (in Fig. 1).

During the Asian summer monsoon period, wind in the lower troposphere is southwesterly over the Western Arabian Sea. The wind speeds at $850 \mathrm{hpa}$ usually exceeds $\sim 10 \mathrm{~ms}^{-1}$ during June-September. The highest wind speeds exceeding $15 \mathrm{~ms}^{-1}$ are observed during July in the geographical region between $5^{\circ} \mathrm{N}$ to $15^{\circ} \mathrm{N}$ at $50^{\circ} \mathrm{E}$ to $60^{\circ} \mathrm{E}$ (Somalia jet) longitude. The Somalia jet wind speed increases from $\sim 15 \mathrm{~ms}^{-1}$ in June to more than $20 \mathrm{~ms}^{-1}$ in July, and decreases subsequently to $\sim 15 \mathrm{~ms}^{-1}$ in August and $\sim 10 \mathrm{~ms}^{-1}$ in September. Such wind speeds correspond to an eastward airmass transport of about 850 to $1700 \mathrm{~km}$ per day and hence the travel time of an air parcel from the western border of the Arabian Sea to the west coast of India will be about 2 to 4 days. This atmospheric circulation leads to the transport of large amount of aerosols from the dust-laden areas of Arabia and is one of the main reasons for the very high AOD values observed during the summer monsoon season over the Arabian Sea. Note that the westerly wind speed increases from June to July over the west Arabian Sea. Associated with this, the absolute value of the AOD over the Arabian Sea, as well as the area covered by the large aerosol plume, increase from June to July. The westerly wind speed slightly decreases in August, leading to an overall decrease in AOD over the Arabian Sea. The westerly winds over the west Arabian Sea further weakens during September, which is clearly associated with a decrease in the observed AOD over the Arabian Sea, as seen in Fig. 1.

The prominent feature observed during the summer monsoon period is the high AOD over the Arabian Sea sector, especially near $15^{\circ} \mathrm{N}$ latitude. This feature, which is well pronounced in July, is further examined in light of prevailing circulation. As seen from Fig. 1, the prominent feature in the wind is the strong southwesterlies over the west Arabian Sea north of the equator up to $\sim 18^{\circ} \mathrm{N}$. Near the continent the wind is mostly westerly or northwesterly. This feature becomes more pronounced at higher altitudes. In order to examine the association of AOD distribution and circulation, the AOD and wind pattern in the month of July (typically July 2003) is examined in detail. Figure 9b shows the regional distribution of AOD in July 2003, along with a wind field at four typical pressure levels, 925, 850, 700 and $500 \mathrm{hpa}$, which correspond to approximately $0.8,1.5,3$ and $5 \mathrm{~km}$ altitudes, respectively. The slow change in the wind pattern with height is observable in Fig. 9b. From this figure it can be seen that the wind pattern favorable for the transport of dust aerosols from Arabia occurs around the 850-to 700-hpa level (i.e. between 1.5 and $3.0 \mathrm{~km}$ ) during the summer monsoon season. Below this region the wind pattern (southerly winds) is not conducive for the observed AOD pattern. Thus, the observed high in AOD would have been significantly contributed by the increased aerosol loading in the altitude region 1.5 to $3 \mathrm{~km}$. We have also examined the 7day air back trajectories ending at $15^{\circ} \mathrm{N}, 70^{\circ} \mathrm{E}$ at 4 different levels $(0,1.0,2.0$ and $4.0 \mathrm{~km}$ above the surface) for all days in July 2003 obtained from the NOAA-ARL-HYSPLIT model. These are presented in Figs. 10i-l. The colors in each trajectory indicate the altitudes of the air parcel at each location along its path. Figure 10i shows that near the surface all trajectories are confined to near-surface and originate from the Southern Hemispheric oceanic region. The situation is more or less the same for $1 \mathrm{~km}$ altitude as well (Fig. 10j), except for the fact that a few trajectories from western landmasses are also being added to the cluster. The back trajectories in Fig. 10k show advection of the boundary layer aerosols ( 0 to $1.5 \mathrm{~km}$ ) emanating from the arid west Asian regions (deserts), ascending to $\sim 2 \mathrm{~km}$ at $15^{\circ} \mathrm{N}$. The air trajectories at $3 \mathrm{~km}$ (not shown here) also mostly originate from lower altitudes over the western arid continents. This shows advection of lower tropospheric (particularly with altitude $\sim 1-$ $2 \mathrm{~km}$ ) air from the Arabian desert region and northwest of the Indian subcontinent (including Pakistan and Afghanistan). Combining features from Figs. 9 and 10, it can be inferred that the high AOD observed in this region would have been contributed by transport of mineral dust from the adjacent arid Arabian region. However, as wind speeds are large near the surface there would be a significant contribution of seasalt aerosols through in-situ production, as well as by advection from southern oceanic region.

The easterly winds from Southeast Asia also transport significant amounts of aerosols from the Southeast Asian region over to the Bay of Bengal. This transport is largest during January-April. However, during the El Niño years, the intense forest fires in the Indonesian region caused large transport of smoke into the equatorial Indian Ocean that was largely aided by the reversal of winds into strong easterlies in the eastern equatorial Indian Ocean during the El Niño years, compared to the westerlies in this region during the normal/La Niña years (Nakajima et al., 1999; Parameswaran et al., 2004). This is the reason for the high AOD values in the eastern equatorial Indian Ocean during the SeptemberNovember period of 1997, as seen Fig. 6.

In addition to the transport of aerosols from the continental areas, the sea-salt produced by the surface wind also contributes to the observed AOD over the oceanic areas. This is significant in the regions of high wind speed, such as 
the Southern Hemispheric Indian Ocean between $10^{\circ} \mathrm{S}$ and $20^{\circ} \mathrm{S}$ throughout the year, and the Arabian Sea during the summer monsoon season. Several models are available in the literature on the dependence of sea-salt concentration with wind speed (e.g. Erickson et al., 1986; Gong et al., 1997), and most of them predict an exponential relationship between the sea-salt concentration and the near-surface wind speed. However, significant differences exist between different models as far as the coefficients relating the wind speed and the sea-salt aerosol concentration are concerned. This aspect may be kept in mind while calculating the sea-salt contribution to AOD and interpreting the results. Our aim here is mainly to identify the regions and periods when the seasalt contribution is significant, and have an estimation of the sea-salt contribution to AOD for inferring the non-sea-salt contribution to the observed AOD. Based on the relationship proposed by Erickson et al. (1986), the sea-salt contribution to the AOD $\left(\tau_{s s}\right)$ can be expressed as an exponential function of near-surface wind speed, $U$, in $\mathrm{ms}^{-1}$ of the form $\tau_{s s}$ $=\tau_{s s 0} e^{0.16 U}$, where $\tau_{s s 0}$ is the optical depth due to sea-salt aerosols at $U=0 \mathrm{~ms}^{-1}$. The value of $\tau_{s s 0}$ is taken as 0.02 , which is the minimum AOD observed over the oceanic areas in the present study. The values of $U$ are taken from the surface wind data obtained from the NCEP-NCAR reanalysis (Kalnay et al., 1996). Figure 11a shows the seasonal mean contour maps of the estimated sea-salt contribution to AOD $\left(\tau_{s s}\right)$ during 1996-2003.

The estimated values of $\tau_{s s}$ are $\leq 0.04$ over the Northern Hemispheric oceanic regions during the Asian dry season (November-January and February -April). However, the estimated value of $\tau_{s s}$ during the Asian summer monsoon season is greater than 0.08 over a wide region, over the western Arabian Sea and exceeds 0.10 in the region of the Somalia Jet. The value of $\tau_{s s}$ during the summer monsoon is $\leq 0.06$ over the Bay of Bengal. In most of the regions over the Southern Hemisphere Indian Ocean, $\tau_{s s}$ is $>0.06$ throughout the year and is greater than 0.08 around $15^{\circ} \mathrm{S}-20^{\circ} \mathrm{S}$ in the central and eastern Indian Ocean during November-January and June-September periods. The minimum value of $\tau_{s s}$ in the SHIO is observed during the February-April period.

The non-sea-salt contribution $\left(\tau_{n s s}\right)$ to the observed AOD is inferred by subtracting the estimated values of $\tau_{s s}$ from the observed AOD. The seasonal mean maps of the inferred $\tau_{n s s}$ during the November- January, February-April and JuneSeptember periods averaged for 1996-2003 are shown in Fig. 11b. In the Northern Hemisphere, during the Asian dry period the value of $\tau_{n s s}$ is considerably larger than that of $\tau_{s s}$. Similar to the total AOD, values of $\tau_{n s s}$ are also higher in the southeast Arabian Sea and North Bay of Bengal during the Asian dry period in general and during the FebruaryApril period in particular. Even though very high values of AOD observed over the Arabian Sea during the summer monsoon are significantly contributed by the non-sea-salt aerosols $(\sim 0.3)$, the contribution from sea-salt $(\sim 0.1)$ is not negligible. Over the Bay of Bengal, $\tau_{s s}$ is more than $\sim 30 \%$ of $\tau_{n s s}$ during the summer monsoon season. Over the Southern Hemisphere Indian Ocean, $\tau_{n s s}$ accounts for about half of the observed AOD, and the zones of highest AOD in this region coincides with the zones where $\tau_{s s}$ is also the highest, except in the western equatorial Indian Ocean near Indonesia, which was significantly influenced by the forest fire related smoke plume during September-November of 1997.

\section{Conclusions}

The monthly and seasonal mean regional aerosol distributions over the Arabian Sea, Bay of Bengal, and the Indian Ocean during the seven-year period of November 1995December 2003 (with a break in year 2000) are studied using the AOD derived from NOAA-14 and NOAA-16 AVHRR data. The main objectives of this study are (a) to assess the interannual variability in the regional AOD distribution, and (b) to provide a longer-term average of regional mean AOD distribution (compared to the existing 3-4 year averages reported in the literature), so that biases in the regional mean AODs, where the interannual variability in AOD is high, can be minimized. Probable altitude regions and pathways of continental aerosol transport are studied, and the contribution of the sea-salt AOD to the observed AOD is estimated. The main conclusions are:

1. The geographical pattern of the regional aerosol distribution is remarkably consistent from year to year over most of the areas in the Arabian Sea, Bay of Bengal and Indian Ocean. The major difference in this pattern occurs in the eastern equatorial Indian Ocean during the periods of the intense El Niño years, which are associated with intense forest fires in Indonesia.

2. The annual variation in AOD is largest in coastal Arabia and least in the Southern Hemisphere Indian Ocean. The regional mean AOD over the Arabian Sea, Bay of Bengal, and Indian Ocean also undergoes systematic annual variation. In the Arabian Sea highest value of AOD ( 0.34) is encountered in July and the lowest value $(\sim 0.17)$ in November. In the Bay of Bengal region, the highest value $(\sim 0.26)$ is observed in March and the lowest value $(\sim 0.12)$ in August-September.

3. The AOD over the Southern Hemisphere Indian Ocean is significantly low; the maximum regional mean AOD in this region is $\sim 0.13$, occurring in October and the minimum AOD of $\sim 0.07$ occurs during January to May.

4. A large latitude gradient in AOD is observed in the region north of equator. Highest latitude gradients are observed in July over the Arabian Sea in the $40^{\circ} \mathrm{E}$ to $70^{\circ} \mathrm{E}$ longitude sector and in March over Bay of Bengal in the $90^{\circ} \mathrm{E}$ to $100^{\circ} \mathrm{E}$ longitude sector. The minimum latitude gradient is observed in October at both longitude sectors. The mean latitude gradient for the entire region $20^{\circ} \mathrm{S}$ to $20^{\circ} \mathrm{N}$ in the entire longitude sector $\left(40^{\circ} \mathrm{E}\right.$ to $100^{\circ} \mathrm{E}$ ) considered in the present study is a minimum in September/October. 


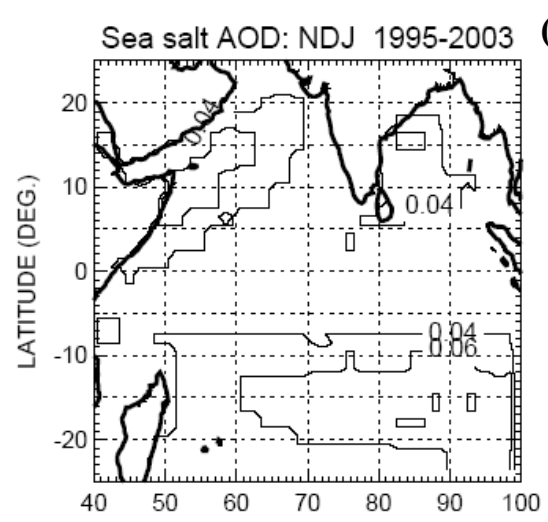

(a)
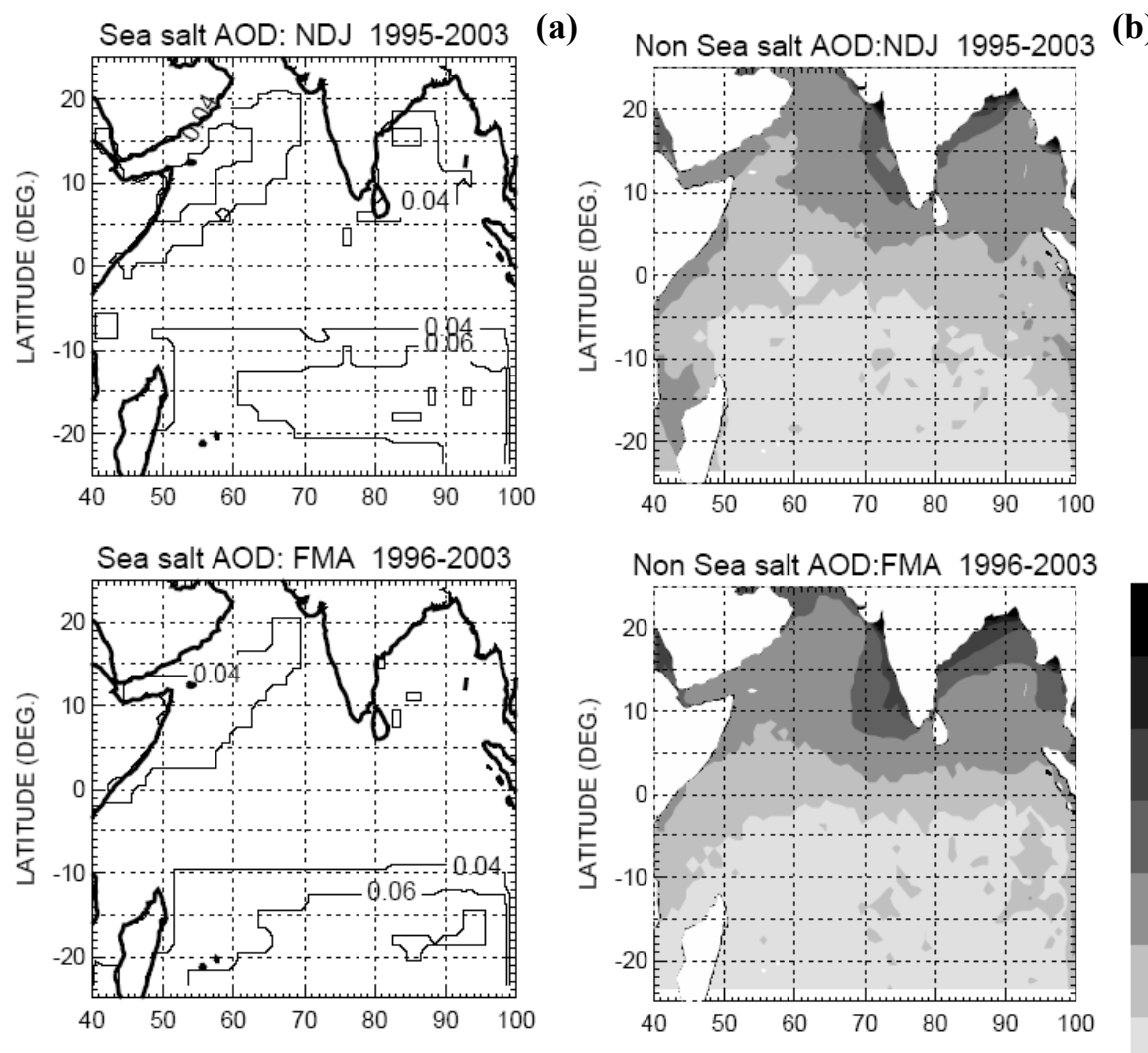

0.60

0.50
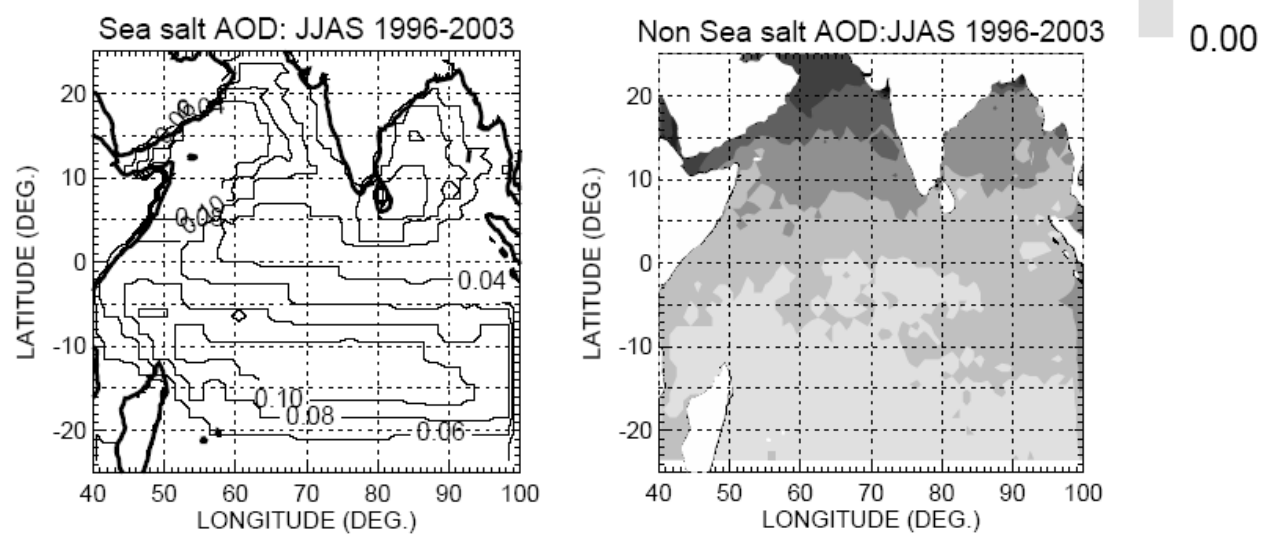

Fig. 11. Contour maps of estimated sea-salt component of AOD $\left(\tau_{s s}\right)$ during November-January, February-April and June-September period of 1995-2003 (a) and contour maps of inferred non-sea-salt component of AOD $\left(\tau_{n s s}\right)$ during the same period (b).

5. The absolute values of the seasonal mean AOD undergoes considerable interannual variations over the Northern Hemisphere. Over the Northern Hemisphere oceanic region, the interannual variability is the least during the first half of the Asian dry season (NovemberJanuary period). The largest interannual variability $(\sim 50 \%)$ is observed during the second half of the Asian dry period (February-April) over the southeastern Arabian Sea and North Bay of Bengal. The interannual variability in these two regions during the summer monsoon season and in most of the other regions for all seasons are less than $30 \%$. interannual variability is the least in the Southern Hemispheric Indian Ocean for all seasons.

6. Large values of AOD observed over the Arabian Sea during the summer monsoon season are mainly due to the transport of mineral dust from the Arabian Desert. The sea-salt contribution to AOD, due to high surface wind, is also highest in the summer monsoon season over the western Arabian Sea (near the Somalia Jet region, it is $\geq 0.1$ ). During the Asian dry season, over the Arabian Sea and Bay of Bengal the sea-salt contribution to the observed AOD is significantly less than the non-sea-salt contribution. 
Much of the interannual variability in the observed AOD over the Northern Hemisphere during the second half of the Asian dry period is due to the changes in the lower tropospheric circulation. However, the impact of the aerosol loading and its variations on the atmospheric circulation itself need to be studied based on models. Furthermore, the effect of the weak and active phases of the summer monsoon on the aerosol loading over the Arabian Sea region is also to be examined in detail.

Acknowledgements. The NOAA14/NOAA16 AVHRR data is obtained from the NOAA Satellite Active Archive. The authors gratefully acknowledge the NOAA Air Resources Laboratory (ARL) for the provision of the HYSPLIT transport and dispersion model and READY website (http://www.arl.noaa.gov/ready.html) used in this publication. The NCEP/NCAR reanalysis is provided by the NOAA-CIRES Climate Diagnostics Center, Boulder Colorado from their web site at http://www.cdc.noaa.gov. This work is part of ISRO-GBP. S. K. Nair acknowledges the financial support through ISRO Research Fellowship.

Topical Editor O. Boucher thanks K. Niranjan and B. V. Krishna Murthy for their help in evaluating this paper.

\section{References}

Ansmann, A., Althausen, D., Wandinger, U., Franke, K., Muller, D., Wagner, F., and Heintzenberg, J.: Vertical profiling of the Indian aerosol plume with six-wavelength lidar during INDOEX: a first case study, Geophys. Res. Lett., 27, 963-966, 2000.

Charlson, R. J., Schwartz, S. E., Hales, J. M., Cess, R. D., Coakley, J. A., Hansen, J. E., and Hoffmann, D. J.: Climate forcing by anthropogenic aerosols, Science, 255, 423-43, 1992.

Dubovik, O., Holben, B., Eck, T. F., Smirnov, A., Kaufman, Y. J., King, M. D., Tanre, D., and Slutsker, I.: Variability of absorption and optical properties of key aerosol types observed in worldwide locations, J. Atmos. Sci., 59, 590-608, 2002.

Draxler, R. R. and Rolph, G. D.: HYSPLIT (HYbrid Single-Particle Lagrangian Integrated Trajectory) Model access via NOAA ARL READY Website (http://www.arl.noaa.gov/ready/hysplit4.html) NOAA Air Resources Laboratory, Silver Spring, MD, 2003.

Erickson, D. J., Merill, J. T., and Duce, R. A.: Seasonal estimates of global atmospheric sea-salt distribution, J. Geophys. Res., 91, 1067-1072, 1986.

Eck, T. F., Holben, B. N., Dubovik, O., Smirnov, A., Slutsker, I., Lobert, J. M., and Ramanathan, V.: Column-integrated aerosol optical properties over the Maldives during the northeast monsoon for 1998-2000, J. Geophys. Res., 106, 28 555-28 566, 2001.

Gong, S. L., Barrie, L. A., and Blanchet, J. P.: Modeling seasalt aerosols in the atmosphere. 1.Model development, J. Geophys. Res., 102, 3805-3818, 1997.

Hansen, J., Sato, M., and Ruedy, R.: Radiative forcing and climate response, J. Geophys. Res., 102, 6831-6864, 1997.

Holben, B. N., Tanre, D., Smirnov, A., Eck, T. F., Slutsker, I., Abuhassan, N., Newcomb, W. W., Schafer, J., Chatenet, B., Lavenue, F., Kaufman, Y. J., Vande Castle, J., Setzer, A., Markham, B., Clark, D., Frouin, R., Halthore, R., Karnieli, A., O’Neill, N. T., Pietras, C., Pinker, R. T., Voss, K., and Zibordi, G.: An emerging ground-based aerosol climatology: Aerosol Optical Depth from AERONET, J. Geophys. Res., 106, 12 067-12 097, 2001.
Husar, R. B., Prospero, J. M., and Stowe, L. L.: Characterization of tropospheric aerosols over the ocean with the NOAA AVHRR optical thickness operational product, J. Geophys. Res., 102, 16889-16909, 1997.

Kalnay, E., Kanamitsu, M., Kistler, R., Collins, W., Deaven, D., Gandin, L., Iredell, M., Saha, S., White, G., Woollen, J., Zhu, Y., Chelliah, M., Ebisuzaki, W., Higgins, W., Janowiak, J., Mo, K.C., Ropelewski, C., Wang, J., Leetmaa, A., Reynolds, R., Jenne, R., and Joseph, D.: The NCEP/NCAR Reanalysis 40-year Project, Bull. Am. Meteorol. Soc., 77, 437-471, 1996.

Kaufman, Y. J., Tanre, D., Dubovik, O., Karnieli, A., and Remer, L. A.: Absorption of sunlight by dust as inferred from satellite and ground-based remote sensing, Geophys. Res.Lett., 28, 14791482, 2001.

Krishnamurti, T. N., Jha, B., Prospero, J., Jayaraman, A., and Ramanathan, V.: Aerosol and pollutant transport and their impact on radiative forcing over the tropical Indian Ocean during the January-February 1996 pre-INDOEX cruise, Tellus, 50B, 521542, 1998.

Lelieveld, J., Crutzen, P. J., Ramanathan, V., Andreae, M. O., Brenninkmeijer, C. A. M., Campos, T., Cass, G. R., Dickerson, R. R., Fischer, H., De Gouw, J. A., Hansel, A., Jefferson, A., Kley, D., De Laat, A. T. J., Lal, S., Lawrence, M. G., Lobert, J. M., Mayol-Bracero, O. L., Mitra, A. P., Novakov, T., Oltmans, S. J., Prather, K. A., Reiner, T., Rodhe, H., Scheeren, H. A., Sikka, D., and Williams, J.: The Indian Ocean Experiment: Widespread air pollution from South and Southeast Asia, Science, 291, 10311036, 2001.

Leon J.-F., Chazette, P., Dulac, F., Pelon, J., Flamant, C., Bonazzola, M., Foret, G., Alfaro, S. C., Cachier, H., Cautenet., S., Hamonou., E., Gaudichet, A., Gomes, L., Rajot, J.-L., Lavenu, F., Inamdar, S. R., Sarode, P. R., and Kadadevarmath, J. S.: Largescale advection of continental aerosols during INDOEX, J. Geophys. Res., 106, 28 427-28 439, 2001.

Li, F. and Ramanathan, V.: Winter to summer monsoon variation of aerosol optical depth over the tropical Indian Ocean, J. Geophys. Res., 107, doi:10.1029/2001JD000949, 2002.

Mishchenko, M., Geogdzhayev, I. V., Cairns, B., Rossow, W. B., and Lacis, A. A.: Aerosol retrievals over the ocean by use of channels 1 and 2 AVHRR data: sensitivity analysis and preliminary results, Appl. Opt., 38, 7325-7341, 1999.

Moorthy, K. K., Nair, P. R., Prasad, B. S. N., MuraliKrishnan, N., Gayathri, H. B., Narasimha Murthy, B., Niranjan, K., Ramesh Babu, V., Satyanarayana, G. V., Agashe, V. V., Aher, G. R, Singh, R., and Srivastava, B. N.: Results from the MWR network of IMAP, Indian J. Radio Space Phys., 22, 243-258, 1993.

Muller, D., Franke, K., Wagner, F., Althausen, D., Ansmann, A., and Heintzenberg, J.: Vertical profiling of optical and physical particle properties over the tropical Indian Ocean with sizwavelength lidar. 1. Seasonal cycle, J. Geophys. Res., 106, 28 567-28 575, 2001.

Nair, S. K., Rajeev, K., and Parameswaran, K.: Winter time regional aerosol distribution and the influence of continental transport over the Indian Ocean, J. Atmos. Sol. Terr. Phys., 65, 149$165,2003$.

Nakajima, T., Higurashi, A., Takeuchi, N., and Herman, J. R.: Satellite and ground-based study of aerosol properties of 1997 Indonesian forest fire aerosols, Geophys. Res. Lett., 26, 2421-2424, 1999.

Parameswaran, K., Nair, S. K., and Rajeev, K. : Impact of Indonesian forest fires during the 1997 El Niño on the aerosol distribution over the Indian Ocean, Adv. Space Res., 33, 1098-1103, 
2004.

Rajeev, K., Ramanathan, V., and Meywerk, J.: Regional aerosol distribution and its long-range transport over the Indian Ocean, J. Geophys. Res., 105, 2029-2043, 2000.

Rajeev, K. and Ramanathan, V.: Direct observations of clear-sky aerosol radiative forcing from space during the Indian Ocean Experiment, J. Geophys. Res., 106, 17, 221-17, 236, 2000.

Rajeev, K., Nair, S. K., Parameswaran, K., and Raju, C. S.: Satellite observations of the regional aerosol distribution and transport over the Arabian Sea, Bay of Bengal, and Indian Ocean, Indian J. Marine Sciences, 33, 11-29, 2004.

Ramachandran, S.: Spectral aerosol optical characteristics during the northeast monsoon over the Arabian Sea and the tropical Indian Ocean: 1. Aerosol optical depths and their variabilities, J. Geophys. Res., 109, D19207, doi:10.1029/2003JD004476, 2004.

Ramanathan, V., Crutzen, P. J., Lelieveld, J., Mitra, A. P., Althausen, D., Anderson, J., Andreae, M. O., Cantrell, W., Cass, G. R., Chung, C. E., Clarke, A. D., Coakley, J. A., Collins, W. D., Conant, W. C., Dulac, F., Heintzenberg, J., Heymsfield, A. J., Holben, B., Howell, S., Hudson, J., Jayaraman, A., Kiehl, J. T., Krishnamurti, T. N., Lubin, D., McFarquhar, G., Novakov, T., Ogren, J. A., Podgorny, I. A., Prather, K., Priestley, K., Prospero, J. M., Quinn, P. K., Rajeev, K., Rasch, P., Rupert, S., Sadourny, R., Satheesh, S. K., Shaw, G. E., Sheridan, P., and Valero, F. P. J.: Indian Ocean Experiment: An integrated analysis of the climate forcing and effects of the great Indo-Asian haze, J. Geophys. Res., 106, 28, 371-28, 398, 2001a.

Ramanathan, V., Crutzen, P. J., Kiehl, J. T., and Rosenfeld, D.: Aerosols, Climate and The Hydrological Cycle, Science, 294, 2119-2124, 2001b.

Ramana, M. V., Ramanathan, V., Podgorny, I. A., Pradhan, B. B., and Shrestha, B.: The Direct Observations of Large Aerosol Radiative Forcing in the Himalayan Region, Geophys. Res. Lett., 31, doi:10.1029/2003GL018824, GL018824, 2004.

Rao, C. R. N. and Chen, J.: Revised post launch calibration of the visible and near infrared channels of the advanced very highresolution radiometer (AVHRR) on the NOAA-14 spacecraft, Int. J. Remote. Sens., 20 (18), 3485-3491, 1999.
Rasch, P. J., Collins, W. D., and Eaton, B. E.: Understanding the Indian Ocean Experiment (INDOEX) aerosol distributions with aerosol assimilation, J. Geophys. Res., 106, 7337-7355, 2001.

Rolph, G. D.: Real-time Environmental Applications and Display sYstem (READY) Website (http://www.arl.noaa.gov/ready/ hysplit4.html) NOAA Air Resources Laboratory, Silver Spring, MD, 2003.

Satheesh, S. K., Moorthy, K. K., and Murthy, B. V. K.: Spatial gradients in aerosol characteristics over the Arabian Sea and Indian Ocean, J. Geophys. Res., 103, 26 183-26 192, 1998.

Satheesh, S. K. and Srinivasan, J.: Enhanced aerosol loading over Arabian Sea during pre-monsoon season: Natural or anthropogenic?, Geophys. Res. Lett., 29(18), doi:10.1029/2002GL015687, 2002.

Stamnes, K., Tsay, S.-C., Wiscombe, W., and Jayaweera, K.: A numerically stable algorithm for discrete-ordinate-method radiative transfer in multiple scattering and emitting layered media, Appl. Opt., 27, 2502-2509, 1998.

Tahnk, W. R. and Coakley Jr., J. A.: Aerosol optical depth and direct radiative forcing for INDOEX derived from AVHRR: Observations, January-March 1996-2000, J. Geophys. Res., 107, No. D19, 8010, doi:10.1029/2000JD000183, 2002.

Takemura, T., Nakajima, T., Holben, B. N., and Kinne, S.: Single scattering albedo and radiative forcing of various aerosol species with a global three-dimensional model, J. Clim., 15, 333-352, 2002.

Verver, G. H. L., Sikka, D. R., Lobert, J. M., Stossmeister, G., and Zachariasse, M.: Overview of the meteorological conditions and atmospheric transport processes during INDOEX 1999, J. Geophys. Res., 106, 28 399-28 413, 2001.

Vinoj, V. and Satheesh, S. K.: Measurements of aerosol optical depth over Arabian Sea during summer monsoon season, Geophys. Res. Lett., 30, doi:10.1029/2002GL016664, 2003.

Vinoj, V., Satheesh, S. K., Suresh Babu, S., and Moorthy, K. K.: Large aerosol optical depths observed at an urban location in southern India associated with rain-deficit summer monsoon, Ann. Geophys., 22, 3073-3077, 2004,

SRef-ID: 1432-0576/ag/2004-22-3073. 